\title{
Comprehensive Insight into Lake Nasser Environment: Water Quality and Biotic Communities-A Case Study before Operating the Renaissance Dam
}

\author{
Mohamed E. Goher ${ }^{1} \mathbb{D}$, Agnieszka Napiórkowska-Krzebietke ${ }^{2, *} \mathbb{D}$, Walid Aly ${ }^{1} \mathbb{D}$, Seliem M. El-Sayed ${ }^{1}$, \\ Usama M. Tahoun ${ }^{1}{ }^{\circledR}$, Mohamed A. Fetouh ${ }^{1}$, Mahmoud H. Hegab ${ }^{1}$, Amany M. Haroon ${ }^{1} \oplus$, Soaad A. Sabae ${ }^{1}$, \\ Eman I. Abdel-Aal ${ }^{1}$, Marian G. Nassif ${ }^{1}$ and Abd Ellatif M. Hussian ${ }^{3}$ (i)
}

1 National Institute of Oceanography and Fisheries (NIOF), Cairo 11694, Egypt; smgoher@yahoo.com (M.E.G.); walid.soton@gmail.com (W.A.); seliemdabour@gmail.com (S.M.E.-S.); usamatahoun@yahoo.com (U.M.T.); ma_fotouh@outlook.com (M.A.F.); hegabmh@yahoo.com (M.H.H.); amanyharoon30@yahoo.com (A.M.H.); soaadsabae@hotmail.com (S.A.S.); emanibrahim2002@gmail.com (E.I.A.-A.); george.marian@hotmail.com (M.G.N.)

2 Department of Ichthyology, Hydrobiology and Aquatic Ecology, S. Sakowicz Inland Fisheries Institute, Oczapowskiego 10, 10-719 Olsztyn, Poland

3 Faculty of Education, Matrouh University, Marsa Matrouh 51511, Egypt; abdellatif_elgoaabar@yahoo.com

* Correspondence: a.napiorkowska-krzebietke@infish.com.pl

Citation: Goher, M.E.;

Napiórkowska-Krzebietke, A.; Aly, W.; El-Sayed, S.M.; Tahoun, U.M.; Fetouh, M.A.; Hegab, M.H.; Haroon, A.M.; Sabae, S.A.; Abdel-Aal, E.I.; et al. Comprehensive Insight into Lake Nasser Environment: Water Quality and Biotic Communities-A Case Study before Operating the Renaissance Dam. Water 2021, 13, 2195. https://doi.org/10.3390/ w13162195

Academic Editor: Shiming Ding

Received: 3 July 2021

Accepted: 8 August 2021

Published: 11 August 2021

Publisher's Note: MDPI stays neutral with regard to jurisdictional claims in published maps and institutional affiliations.

Copyright: ( $\odot 2021$ by the authors Licensee MDPI, Basel, Switzerland. This article is an open access article distributed under the terms and conditions of the Creative Commons Attribution (CC BY) license (https:// creativecommons.org/licenses/by/ $4.0 /)$.
Abstract: This study focused on the monitoring and assessment of aquatic ecosystem functioning based on the abiotic and biotic features of Lake Nasser in the post-flood and pre-flood periods as the last ones before water storing behind the Grand Ethiopian Renaissance Dam. The physicochemical parameters, distribution and structure of biotic communities, including bacteria, phytoplankton, zooplankton, macrophytes, epiphytes and fish were analyzed at 15 sites. The values of most parameters (primarily temperature, total suspended solids, $\mathrm{pH}$, orthophosphates, carbonates, sulphates and some cations) were higher in the pre-flood period, whereas higher values of conductivity, total dissolved solids, total solids, nitrites, nitrates, chemical oxygen demand, bicarbonates and chlorophyll $a$ were recorded in the post-flood period. Cyanobacteria-dominated phytoplankton and total coliform bacteria were more abundant in the pre-flood period, and especially at sites 10-15, whereas higher abundances of zooplankton were recorded in the post-flood period. All these changes in parameters were significantly differentiated, and only the concentrations of dissolved oxygen, biochemical oxygen demand, ammonium and silicates were at similar level in both periods. The study also indicated that environmental factors had affected the macrophyte distribution and the adaptation of the invasive species Myriophyllum spicatum to thrive under different environmental factors in the lake. Besides, macrophytes provided the habitat to other aquatic organisms, especially epiphytes, and also helped maintaining the good water quality, nutrient cycling and stabilizing rivers' and lakes' banks. Generally, these conditions were rather favorable for biological processes and fish production.

Keywords: phytoplankton; zooplankton; macrophytes and epiphytes; bacteria; fish; physicochemical parameters; quality assessment

\section{Introduction}

The construction of the Aswan High Dam (AHD, 1959-1970) in the southern part of Egypt resulted in the creation of one of the largest manmade lakes in the world. The AHD became a multipurpose storage reservoir to provide adequate summer water, hydropower, flood protection and improved river navigation. The whole reservoir extends for about $496 \mathrm{~km}$, including $292 \mathrm{~km}$ for Lake Nasser and $204 \mathrm{~km}$ for Lake Nubia [1]. For the first time floodwaters entered the depression in 1998, and filled it in 2000, which greatly expanded the original reservoir by $25-30 \%$ and added new fishing spots. Lake Nasser, like other lakes in arid regions, is considered an "amplifier lake" in terms of its dramatic response to 
climate changes [2]. Relatively minor variations in the rates of evaporation or precipitation can generate a substantial fall or rise of the lake level and changes in water chemistry. Each change can lead to dramatic shifts in the lake biota and in the composition of sediments accumulating on the lake bottom. The water resources in Egypt are very limited, therefore any future activities and perturbations on the lake should be carefully considered before implementation. The area around the lake should be kept as a natural desert.

Lake Nasser has usually been characterized by good water quality and relatively low nutrient content, which gives an opportunity to grow high-quality freshwater fishes. The lake's waters and sediments have not usually been contaminated with heavy metals [3]. Most of the fishing operations have become more intense in the shallow areas of the lake's khors and on both sides of the main lake's channel. Thus, Lake Nasser constitutes the main source of fish in Upper Egypt and provides value for the economic sector and the number of employees due to the previously limited production from the River Nile and absence of fish farms in this area. The lake is a relatively closed ecosystem with a water retention time of 20 years. Nowadays, the water quality of the lake is affected by many factors including, primarily, inflows, water circulation, thermal stratification, nutrient loadings and sedimentation processes [4-6] related to flooding events. Phytoplankton and zooplankton have become good indicators commonly used for monitoring the environmental conditions [7], and they quickly respond to any changes in the water quality $[8,9]$. Both phytoplankton and zooplankton are, thus, of great importance in the ecological and economic context due to their roles in aquatic food networks and, consequently, in fishery management $[10,11]$. Furthermore, aquatic organisms provide many ecological benefits and are essential in promoting the diversity and function of aquatic systems [12]. Their response to climatic and environmental changes is shown as the variation in density, abundance, domination structure and biodiversity. These important biomarkers of water quality assessment and pollution are known as organisms which are the first to react to any changes and, thus, can provide an early warning signal $[13,14]$. Regular monitoring should be helpful for better water or catchment management and consequently for maintaining at least good water quality in the context of climate and socioeconomic changes [15].

The objectives of this study were to monitor and assess the water quality, distribution and structure of the biotic community, including bacteria, phytoplankton, zooplankton, macrophytes, epiphytes and fish of Lake Nasser in the seasons after and before flooding, i.e., in the so-called post-flood and pre-flood periods. These are the last seasons before the storing of the waters behind the Grand Ethiopian Renaissance Dam (GERD), which already started (in July 2020). That could be useful in future monitoring of the possible changes in Lake Nasser environment before water storage and after completing the filling of the GERD reservoir.

\section{Materials and Methods}

\subsection{Study Area}

Lake Nasser, which occupies about $5237 \mathrm{~km}^{2}$ at $180 \mathrm{~m}$ altitude [3], is situated in the socalled Arabian-Nubian Massif. This area is characterized by four main geomorphological and geological units, including the Aswan Hills, the old Nile Valley and the High Dam reservoir, Lake Nasser, the Nubian Plain and the Sinn El-Kaddab Plateau [16]. The central part at the southern end of the Nubian region is considered to be a fluvial lake where the water flow is very fast $\left(100-150 \mathrm{~cm} \mathrm{~s}^{-1}\right)$. This speed is gradually reduced within a few kilometers to $10-20 \mathrm{~cm} \mathrm{~s}^{-1}$, and the speed of $0-3 \mathrm{~cm} \mathrm{~s}^{-1}$ has been recorded in Lake Nasser. The mean depth in the central part gradually increases from $10 \mathrm{~m}$ at the southern end to $70 \mathrm{~m}$ in the north. Within Lake Nasser exist many embayment and locally dendritic inlets, or side extensions of the reservoir called khors. The total number of important khors is 85 (48 on the eastern side and 37 on the western side). Some khors (Kalabsha, Tushka and Allaqi) are wide and gently sloping, with a sandy bottom, whereas others (Singari, El-Sabajha and Korosko) are steep and relatively narrow, with a rocky bottom [6]. The Tushka Canal links the reservoir to the Tushka Depression. 
Water samples were collected from five sectors in the main channel. These sectors from the north to the south are as follows: Aswan, Wadi Abyade, El-Madiq, Tushka and AbuSimbel. In each sector, three sites were selected (eastern and western banks and additionally the middle in the main channel) to provide a total of 15 sites (Table 1, Figure 1). The sites were chosen to represent the different parts of Lake Nasser and cover the whole lake.

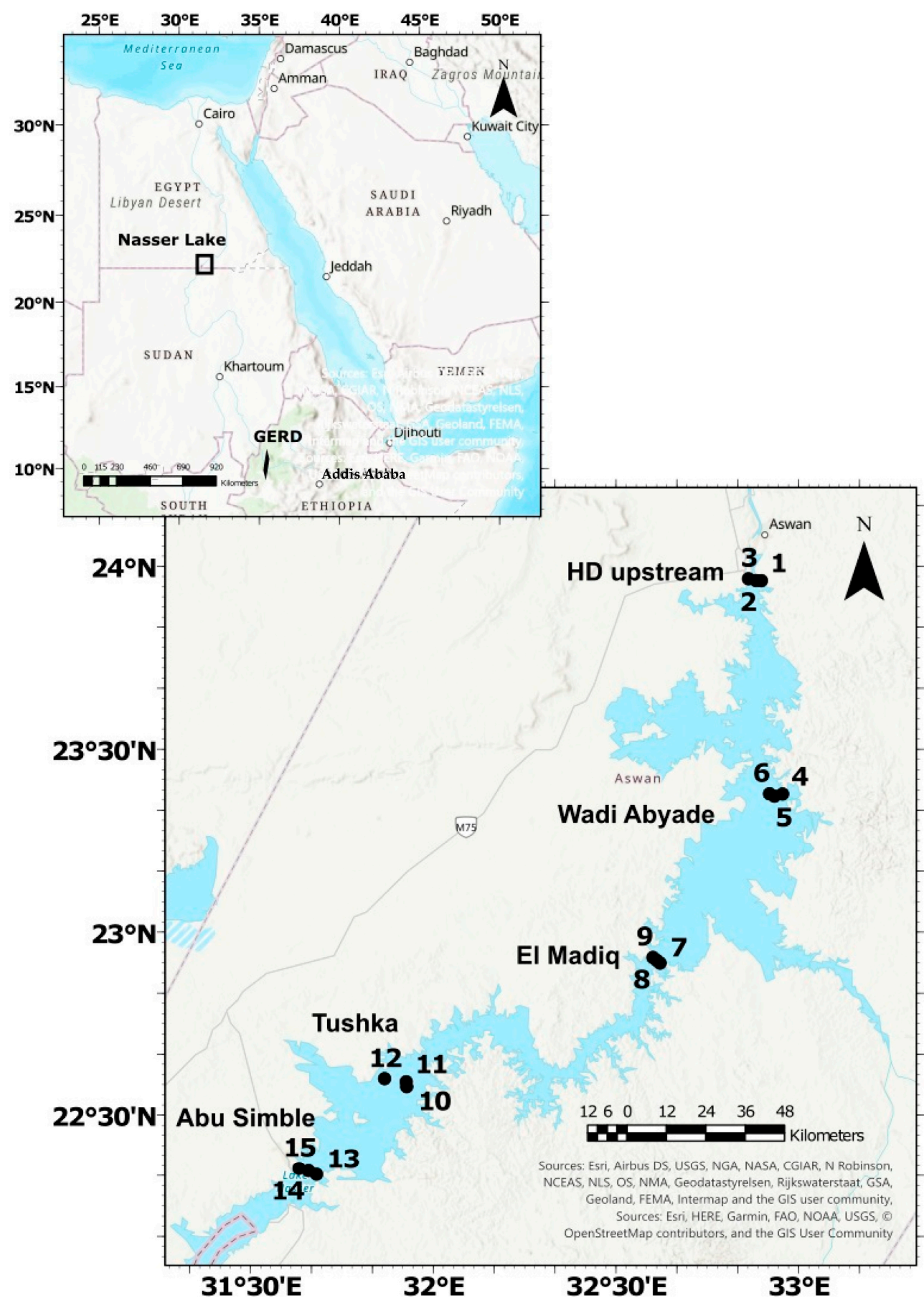

Figure 1. The map of the location and the sampling sites 1-15 in Lake Nasser, GERD—Grand Ethiopian Renaissance Dam. 
Table 1. Geographical coordinates of the sampling sites in Lake Nasser.

\begin{tabular}{|c|c|c|c|c|}
\hline & Sampling Site & & Longitude $\mathbf{N}$ & Latitude E \\
\hline \multirow{3}{*}{ 1. HD upstream } & E1 & 1 & $32^{\circ} 53^{\prime} 53.14^{\prime \prime}$ & $23^{\circ} 57^{\prime} 38.34^{\prime \prime}$ \\
\hline & M1 & 2 & $32^{\circ} 52^{\prime} 59.84^{\prime \prime}$ & $23^{\circ} 57^{\prime} 39.40^{\prime \prime}$ \\
\hline & W1 & 3 & $32^{\circ} 51^{\prime} 45.25^{\prime \prime}$ & $23^{\circ} 57^{\prime} 57.24^{\prime \prime}$ \\
\hline \multirow{3}{*}{ 2. Wadi Abyade } & E2 & 4 & $32^{\circ} 57^{\prime} 21.50^{\prime \prime}$ & $23^{\circ} 22^{\prime} 39.27^{\prime \prime}$ \\
\hline & M2 & 5 & $32^{\circ} 56^{\prime} 02.10^{\prime \prime}$ & $23^{\circ} 22^{\prime} 17.93^{\prime \prime}$ \\
\hline & W2 & 6 & $32^{\circ} 55^{\prime} 13.30^{\prime \prime}$ & $23^{\circ} 22^{\prime} 41.22^{\prime \prime}$ \\
\hline \multirow{3}{*}{ 3. El Madiq } & E3 & 7 & $32^{\circ} 37^{\prime} 14.70^{\prime \prime}$ & $22^{\circ} 54^{\prime} 55.41^{\prime \prime}$ \\
\hline & M3 & 8 & $32^{\circ} 36^{\prime} 43.69^{\prime \prime}$ & $22^{\circ} 55^{\prime} 21.23^{\prime \prime}$ \\
\hline & W3 & 9 & $32^{\circ} 36^{\prime} 04.35^{\prime \prime}$ & $22^{\circ} 55^{\prime} 51.28^{\prime \prime}$ \\
\hline \multirow{3}{*}{ 4.Tushka } & $\mathrm{E} 4$ & 10 & $31^{\circ} 55^{\prime} 38.27^{\prime \prime}$ & $22^{\circ} 34^{\prime} 39.42^{\prime \prime}$ \\
\hline & M4 & 11 & $31^{\circ} 55^{\prime} 33.98^{\prime \prime}$ & $22^{\circ} 35^{\prime} 28.23^{\prime \prime}$ \\
\hline & W4 & 12 & $31^{\circ} 52^{\prime} 00.53^{\prime \prime}$ & $22^{\circ} 35^{\prime} 58.79^{\prime \prime}$ \\
\hline \multirow{3}{*}{ 5. Abu Simble } & E5 & 13 & $31^{\circ} 40^{\prime} 50.66^{\prime \prime}$ & $22^{\circ} 20^{\prime} 11.31^{\prime \prime}$ \\
\hline & M5 & 14 & $31^{\circ} 39^{\prime} 31.38^{\prime \prime}$ & $22^{\circ} 20^{\prime} 47.88^{\prime \prime}$ \\
\hline & W5 & 15 & $31^{\circ} 37^{\prime} 57.75^{\prime \prime}$ & $22^{\circ} 21^{\prime} 10.13^{\prime \prime}$ \\
\hline
\end{tabular}

\subsection{Sampling Program and Methods}

This study was conducted within a comprehensive research program of the National Institute of Oceanography and Fisheries on the environmental conditions and fishery of Lake Nasser. The first campaign was performed in November 2019 (25-30 November $2019)$, i.e., after the flooding season, in the so-called post-flood period, while the second campaign was conducted in June 2020 (22-27 June 2020), i.e., before the flooding seasonthe so-called pre-flood period. The physicochemical parameters and biotic parameters (bacteria including total coliforms, fecal coliforms and fecal streptococci, phytoplankton, zooplankton, macrophytes, epiphytes and fish) were then studied.

\subsection{Physicochemical Parameters}

The subsurface (about $30 \mathrm{~cm}$ ) water samples were collected in polyvinyl chloride Van Dorn plastic bottles ( $2 \mathrm{~L}$ ) from 15 sites on two sampling occasions to provide 30 water samples in total. A Ruttner Water Sampler with the capacity of $2 \mathrm{~L}$ was used to collect the samples which were kept in the well-cleaned plastic bottles. Hydrographic parameters were measured at each site during the sample collection. Glass stoppered oxygen bottles for dissolved oxygen and biochemical oxygen demand were filled carefully with waters from the selected layers and fixed immediately on the spot.

The methods of the American Public Health Association [17] were used for the determination of the majority of the physicochemical parameters. Water temperature $\left({ }^{\circ} \mathrm{C}\right)$, $\mathrm{pH}$ and conductivity (EC, $\mu \mathrm{S} \mathrm{cm}^{-1}$ ) were measured in situ using a Hydrolab model (Multi Set 340i WTW, Weilheim, Germany) after previous calibration. Transparency was measured using a white/black Secchi disk (25 $\mathrm{cm}$ in diameter) and expressed as the Secchi disk depth (SDD). Water alkalinity was determined immediately after sample collection using phenolphthalein and methyl orange indicators. Total solids (TS) were measured by evaporating a known volume of a well-mixed sample. Total dissolved solids (TDS) were determined by filtering a volume of a sample with a glass microfiber filter (GF/C), and a known volume of the filtrate was evaporated at $180^{\circ} \mathrm{C}$. Total suspended solids (TSS) were calculated as the difference between TS and TDS. Dissolved oxygen was measured using the modified Winkler method, biological oxygen demand (BOD) was measured using the 5 -days method. The measurements of chemical oxygen demand (COD) were carried out using the potassium permanganate method. $\mathrm{CO}_{3}{ }^{2-}$ and $\mathrm{HCO}^{3-}$ were measured titrimetrically with standard $\mathrm{H}_{2} \mathrm{SO}_{4}(0.02 \mathrm{~N})$ using phenolphthalein and methyl orange as indicators. Sulphates $\left(\mathrm{SO}_{4}{ }^{2-}\right)$ were determined using the turbidimetric method. Nitrogen-ammonium $\left(\mathrm{N}-\mathrm{NH}_{4}\right)$ was determined by the phenate method. Nitrogen-nitrite $\left(\mathrm{N}-\mathrm{NO}_{2}\right)$ was determined using the colorimetric method with the formation of a reddish-purple azo dye. 
Nitrogen-nitrate $\left(\mathrm{N}-\mathrm{NO}_{3}\right)$ was measured as nitrite after cadmium reduction. Orthophosphates $\left(\mathrm{P}-\mathrm{PO}_{4}\right)$ were estimated using the ascorbic acid molybdate method. Silicates $\left(\mathrm{SiO}_{4}\right)$ were determined using the molybdosilicate method. Chlorides $\left(\mathrm{Cl}^{-}\right)$were measured using the Mohr method, sulphate-by the turbidimetric method. Calcium $\left(\mathrm{Ca}^{2+}\right)$ and magnesium $\left(\mathrm{Mg}^{2+}\right)$ were determined by direct titration using the EDTA solution, while sodium $\left(\mathrm{Na}^{+}\right)$ and potassium $\left(\mathrm{K}^{+}\right)$were measured directly using a flame photometer model Jenway PFP7 (Cole-Parmer, Staffordshire, United Kingdom).

\subsection{Bacteria}

The total of 30 samples were taken from 15 sites on two sampling occasions, i.e., during the post- and pre-flood periods. The bacteriology of the water samples was analyzed according to the standard methods of the American Public Health Association [17]. Total viable bacterial counts (TVBC) were enumerated at two different temperatures, at $22{ }^{\circ} \mathrm{C}$ and at $37^{\circ} \mathrm{C}$, using pour plate techniques on nutrient agar (NA) media. Total coliform (TC) and fecal coliform (FC) bacteria were enumerated using the most probable number (MPN) techniques with MacConkey broth media. The tubes were incubated at $37^{\circ} \mathrm{C}$ for $48 \mathrm{~h}$ for $\mathrm{TC}$ and at $44^{\circ} \mathrm{C}$ for $24 \mathrm{~h}$ for FC. Confirmation was performed using positive tubes streaked on eosin methylene blue (EMB) agar plates incubated at $37^{\circ} \mathrm{C}$ for $24 \mathrm{~h}$. Microscopic examination was carried out to ensure detection of Gram-negative non-spore-forming rods. The MPN techniques were used to determine fecal streptococci (FS) using the azide dextrose broth at $37^{\circ} \mathrm{C}$ for $48 \mathrm{~h}$; then, the confirmation test was applied as follows: the positive tube was indicated by dense turbidity and confirmed using the ethyl violet azide dextrose broth incubated at $37^{\circ} \mathrm{C}$ for $24 \mathrm{~h}$. Formation of a purple button at the bottom of tubes confirmed the presence of fecal streptococci.

The membrane filtration method was used for the enumeration of Escherichia coli. Each sample was filtered using filter paper $(0.45 \mu \mathrm{m}$ pore size), and then the filter was carefully transferred into the eosin methylene blue agar medium. The plates were incubated at $44.5^{\circ} \mathrm{C}$ for $24 \mathrm{~h}$. The colonies of $E$. coli (a single cell is $2-3 \mathrm{~mm}$ in diameter, smooth, with the intact edge and green metallic sheen) were counted [17].

$$
\text { E. } \frac{\text { coli }}{100} m L=\frac{\text { Number of E.coli colonies } \times 100}{\text { Volume of the sample filtered }(m L)}
$$

\subsection{Phytoplankton}

Surface water samples were collected from 15 sites in November 2019 (post-flood period) and June 2020 (pre-flood period) using a 1.0 L Ruttner sampler and stored in polyethylene bottles. The water samples were immediately preserved using formalin and Lugol's iodine solution. At the laboratory, the preserved samples were left to settle for 5 days, and the phytoplankton densities (cells $\mathrm{L}^{-1}$ ) were calculated according to the Utermöhl method [18]. The taxonomic identification of phytoplankton followed the newest references, and the currently accepted taxonomic names were confirmed with AlgaeBase [19]. The biological indices, the diversity Shannon-Weaver index (SI) [20], species richness (SR) [21] and evenness (E) [22], were used to evaluate the water status of Lake Nasser.

\subsection{Zooplankton}

The samples for zooplankton analysis were collected from all the 15 sites during the whole study period. The water was sampled with a standard Ruttner water sampler and kept in plastic bottles. At each sampling site, $50 \mathrm{~L}$ of subsurface water were filtered using a plankton net with the 55 micron mesh size. After sampling, the samples were immediately preserved in the $4 \%$ neutral formalin solution until the microscopic examination. The species were identified according to Edmondson [23], Pennak [24] and Verheye and Dumont [25]. 


\subsection{Macrophytes and Epiphytes}

Submerged macrophytes and epiphytes were collected from 10 sampling sites $(1,3,4$, $6,7,9,10,12,13$ and 15 locations) distributed along the eastern and western banks of Lake Nasser during two seasons, i.e., in autumn 2019 (after flooding) and spring 2020 (before flooding). At each site, macrophyte samples were collected by hand, placed in polyethylene bags and stored in lake water before transfer to the laboratory, where they were separated into different taxa and then identified according to Boulos [26].

For epiphyte collection, each macrophyte sample was taken separately to the plastic bottles with addition of deionized water. All the settled organisms were scrapped off the macrophytes many times, and the plants were washed with deionized water several times to completely remove all the attached algae. Epiphytes were separated with vigorous shaking for $3 \mathrm{~min}$, and the process was repeated at least three times. Then, the epiphyte suspension was passed through a $300 \mu \mathrm{m}$ mesh to avoid contamination by small macrophyte fragments [27]. Then, the samples were placed into a $1 \mathrm{~L}$ glass cylinder which was then filled with deionized water. Lugol's iodine solution was also added until the faint tea color was obtained. The epiphytic algal cells were allowed to settle for 5 days. Species identification and counting were performed using an inverted light microscope (Zeiss, Axiovert 25C, Oberkochen, Germany) using a 10× eyepiece under the magnification of $400 \times$. The species were identified similarly to the phytoplankton methods.

\subsection{Fish}

The species composition of the trammel nets, with different specifications depending on the size of the target fish in Ghazel El-Shabar, was investigated in two khors (northern El Ramla khor —at the western side; southeastern Tushka khor—at the eastern side). In general, the khors were selected for fish sampling. The khors represent the main source of fish caught in the lake (about 90\%). Fish samples were taken during the fishing process, and random fishers at Ghazel El-Shabar were additionally interviewed.

\subsection{Statistical Analyses}

All the data were checked with the Shapiro-Wilk normality test, and it was confirmed that the data were not normally distributed. Thus, the nonparametric Mann-Whitney $U$ test was selected to analyze the differences between the abiotic variables in the post-flood and pre-flood periods. The coefficient of variability (CV) was calculated and expressed as percentage. The data were tested with Statistica 13.0 for Windows (Statsoft, Tulsa, OK, USA).

The relationships between planktonic organisms (bacteria, phytoplankton and zooplankton) and the selected environmental parameters were checked with Spearman's correlations and the redundancy analysis (RDA) of canonical ordination and forward selection of variables (the Monte Carlo test with 999 permutations). The parameters used in the analysis were standardized using $\log _{(x+1)}$ transformation. Response data were compositional and had a gradient $0.7 \mathrm{SD}$ units long; thus, a linear method, i.e., RDA, was recommended. The analysis of variance inflation factor (VIF) was used to choose the explanatory variables, and the variables that had a VIF larger than 20 were removed from the analysis [28]. The RDA was performed for planktonic organisms (bacteria, phytoplankton and zooplankton) and thirteen parameters: $\mathrm{T}, \mathrm{EC}, \mathrm{pH}, \mathrm{DO}, \mathrm{BOD}, \mathrm{COD}, \mathrm{NH}_{4}, \mathrm{NO}_{2}, \mathrm{NO}_{3}$, $\mathrm{PO}_{4}, \mathrm{SO}_{4}, \mathrm{SiO}_{4}$ and Chl- $a$. The nonmetric multidimensional scaling (NMDS) analysis based on percentage difference (Bray-Curtis distance) was also used for both plankton organisms and physicochemical parameters. These analyses were performed using the CANOCO 5.0 software for Windows.

\section{Results}

\subsection{Physicochemical Parameters}

The nonparametric Mann-Whitney $U$ test confirmed that the majority of physicochemical parameters were significantly different, comparing all the sampling sites in both 
the post-flood and pre-flood periods (Table 2). The water temperature was usually higher in the pre-flood period $\left(28.4^{\circ} \mathrm{C}\right.$ on average $)$ than in the post-flood $\left(24.5^{\circ} \mathrm{C}\right.$ on average period. Similarly, significantly higher values in the pre-flood period were also noted for TSS, $\mathrm{pH}, \mathrm{PO}_{4}, \mathrm{CO}_{3}, \mathrm{SO}_{4}, \mathrm{Cl}, \mathrm{Ca}, \mathrm{Mg}$, $\mathrm{Na}$ and $\mathrm{K}$, the majority of which were characterized by a relatively low coefficient of variation. The $\mathrm{pH}$ value generally ranged between 8.1 and 8.9. Phosphates were in low concentrations, which amounted to approximately 14.8 and $9.8 \mu \mathrm{g} \mathrm{L}^{-1}$ on average, respectively, in both periods. Similarly, the content of other ions was relatively low.

Table 2. Variability of the physicochemical parameters of water in the post-flood and pre-flood periods.

\begin{tabular}{|c|c|c|c|c|c|c|c|c|c|c|}
\hline \multirow{2}{*}{ Parameter } & \multicolumn{5}{|c|}{ Post-Flood Period } & \multicolumn{5}{|c|}{ Pre-Flood Period } \\
\hline & Min & Max & Mean & SD & $C V, \%$ & Min & $\operatorname{Max}$ & Mean & SD & $\mathrm{CV}, \%$ \\
\hline${ }^{1} \mathrm{~T},{ }^{\circ} \mathrm{C}$ & 23.0 & 28.5 & 24.5 & 1.3 & 5 & 25.5 & 29.7 & 28.4 & 1.2 & 4 \\
\hline${ }^{2} \mathrm{EC}, \mu \mathrm{S} \mathrm{cm}^{-1}$ & 225 & 270 & 245.6 & 13.5 & 6 & 214 & 244 & 230.5 & 11.7 & 5 \\
\hline 3 SDD, $\mathrm{m}$ & 1.8 & 4.0 & 2.7 & 0.8 & 29 & 1.3 & 4.8 & 3.4 & 1.1 & 32 \\
\hline 2 TDS, $\mathrm{mg} \mathrm{L}^{-1}$ & 146.3 & 175.5 & 159.7 & 8.8 & 6 & 139.1 & 158.6 & 149.8 & 7.6 & 5 \\
\hline $1 \mathrm{TSS}^{\mathrm{mg} \mathrm{L}} \mathrm{m}^{-1}$ & 0.8 & 2.9 & 2.0 & 0.7 & 32 & 3.9 & 6.9 & 5.2 & 1.0 & 20 \\
\hline $3 \mathrm{TS}, \mathrm{mg} \mathrm{L}^{-1}$ & 149.1 & 176.3 & 161.7 & 8.5 & 5 & 145.8 & 163.2 & 155.0 & 6.7 & 4 \\
\hline${ }^{1} \mathrm{pH}$ & 8.1 & 8.6 & 8.4 & 0.1 & 1 & 8.3 & 8.9 & 8.7 & 0.2 & 2 \\
\hline $\mathrm{DO}, \mathrm{mg} \mathrm{L}^{-1}$ & 5.0 & 8.0 & 6.5 & 0.9 & 13 & 4.9 & 7.0 & 6.3 & 0.7 & 11 \\
\hline $\mathrm{BOD}, \mathrm{mg} \mathrm{L}^{-1}$ & 1.4 & 5.2 & 2.9 & 1.2 & 42 & 0.8 & 2.9 & 2.0 & 0.7 & 32 \\
\hline${ }^{2} \mathrm{COD}, \mathrm{mg} \mathrm{L}^{-1}$ & 3.7 & 5.7 & 4.8 & 0.6 & 13 & 3.8 & 4.4 & 4.1 & 0.2 & 4 \\
\hline $\mathrm{NH}_{4}, \mu \mathrm{g} \mathrm{L}^{-1}$ & 74.8 & 1343 & 251.7 & 319.3 & 127 & 90.1 & 436.9 & 186.7 & 84.5 & 45 \\
\hline${ }^{1} \mathrm{NO}_{2}, \mu \mathrm{g} \mathrm{L}{ }^{-1}$ & 3.6 & 16.0 & 9.2 & 4.0 & 44 & 1.6 & 7.2 & 3.8 & 1.6 & 41 \\
\hline${ }^{3} \mathrm{NO}_{3}, \mu \mathrm{g} \mathrm{L}{ }^{-1}$ & 40.8 & 657.6 & 153.8 & 193.3 & 126 & 18.4 & 93.6 & 50.5 & 24.1 & 48 \\
\hline${ }^{1} \mathrm{PO}_{4}, \mu g \mathrm{~L}^{-1}$ & 4.4 & 13.2 & 9.8 & 2.5 & 25 & 11.2 & 20.9 & 14.8 & 2.8 & 19 \\
\hline $\mathrm{SiO}_{4}, \mathrm{mg} \mathrm{L}^{-1}$ & 4.4 & 6.7 & 5.4 & 0.6 & 11 & 2.8 & 6.4 & 4.9 & 1.1 & 22 \\
\hline${ }^{2} \mathrm{CO}_{3}, \mathrm{mg} \mathrm{L}^{-1}$ & 0 & 2.4 & 1.3 & 0.7 & 52 & 0 & 4.5 & 2.5 & 1.6 & 63 \\
\hline${ }^{1} \mathrm{HCO}_{3}, \mathrm{mg} \mathrm{L}^{-1}$ & 116.8 & 140.2 & 131.7 & 8.7 & 7 & 90.3 & 109.8 & 99.6 & 7.5 & 8 \\
\hline $3 \mathrm{SO}_{4}, \mathrm{mg} \mathrm{L}^{-1}$ & 3.6 & 5.3 & 4.4 & 0.4 & 10 & 3.8 & 6.1 & 4.9 & 0.6 & 12 \\
\hline${ }^{1} \mathrm{Cl}, \mathrm{mg} \mathrm{L}^{-1}$ & 8.2 & 9.6 & 8.6 & 0.4 & 5 & 9.1 & 9.9 & 9.3 & 0.3 & 3 \\
\hline${ }^{1} \mathrm{Ca}, \mathrm{mg} \mathrm{L}^{-1}$ & 8.0 & 8.7 & 8.4 & 0.2 & 2 & 9.2 & 10.9 & 10.1 & 0.6 & 6 \\
\hline${ }^{1} \mathrm{Mg}, \mathrm{mg} \mathrm{L}^{-1}$ & 6.1 & 7.6 & 6.5 & 0.4 & 6 & 8.1 & 8.7 & 8.4 & 0.2 & 3 \\
\hline $2 \mathrm{Na}, \mathrm{mg} \mathrm{L}^{-1}$ & 9.9 & 11.3 & 10.5 & 0.5 & 4 & 10.3 & 12.2 & 11.3 & 0.7 & 6 \\
\hline${ }^{1} \mathrm{~K}, \mathrm{mg} \mathrm{L}^{-1}$ & 3.4 & 4.1 & 3.7 & 0.2 & 6 & 3.8 & 4.5 & 4.1 & 0.2 & 6 \\
\hline${ }^{1} \mathrm{Chl}^{-a}, \mu \mathrm{g} \mathrm{L} \mathrm{L}^{-1}$ & 19.9 & 102.4 & 53.4 & 25.3 & 19.9 & 19.9 & 102.4 & 53.4 & 25.3 & 47 \\
\hline
\end{tabular}

On the contrary, significantly higher values of EC, TDS, TS, COD, $\mathrm{NO}_{2}, \mathrm{NO}_{3}, \mathrm{HCO}_{3}$ and Chl- $a$ were recorded in the post-flood period. The average values of EC in both periods were 230.5 and $245.6 \mu \mathrm{S} \mathrm{cm}^{-1}$, of TDS-149.8 and $159.7 \mathrm{mg} \mathrm{L}^{-1}$, of TS-155.0 and $161.7 \mathrm{mg} \mathrm{L}^{-1}$, respectively. The chlorophyll $a$ content, in turn, was high and ranged from 19.9 to $102.4 \mu \mathrm{g} \mathrm{L}-1$ and from 10.3 to $43.8 \mu \mathrm{g} \mathrm{L}^{-1}$ in the post-flood and pre-flood periods, respectively. The contents of $\mathrm{DO}, \mathrm{BOD}, \mathrm{NH}_{4}$ and $\mathrm{SiO}_{4}$ were similar in both periods. The values of DO reached 6.3 and $6.5 \mathrm{mg} \mathrm{L}^{-1}$, of BOD-2.0 and $2.9 \mathrm{mg} \mathrm{L}^{-1}$, of $\mathrm{NH}_{4}-186.7$ and $251.7 \mathrm{mg} \mathrm{L}^{-1}, \mathrm{SiO}_{4}-4.9$ and $5.4 \mathrm{mg} \mathrm{L}^{-1}$ on average in the pre-flood and post-flood periods, respectively. The highest $\mathrm{CV}(127 \%)$ was noted for $\mathrm{NH}_{4}$ in the post-flood period; however, it was also similar for $\mathrm{NO}_{3}(126 \%)$. In turn, the lowest $\mathrm{CV}$ was for $\mathrm{pH}(1 \%$ and $2 \%$ in both periods) and $\mathrm{Ca}(2 \%$ in the pre-flood period).

\subsection{Bacteria}

The bacterial assessments based on TVBC at $22{ }^{\circ} \mathrm{C}$ and $37^{\circ} \mathrm{C}$ at the main channel after flooding were between $1.5 \times 10^{3}$ and $135 \times 10^{3} \mathrm{CFU} \mathrm{mL}^{-1}$ and between $1 \times 10^{3}$ and $110 \times 10^{3} \mathrm{CFU} \mathrm{mL} \mathrm{m}^{-1}$, respectively (Table 3). TVBC at $22^{\circ} \mathrm{C}$ and $37^{\circ} \mathrm{C}$ before flooding were lower than after flooding and varied in a narrower range, i.e., between $0.8 \times 10^{3}$ and $34 \times 10^{3} \mathrm{CFU} \mathrm{mL}{ }^{-1}$ and between $0.9 \times 10^{3}$ and $32 \times 10^{3} \mathrm{CFU} \mathrm{mL}^{-1}$, respectively (Table 4). 
Table 3. Bacterial assessment of the main channel of Lake Nasser after flooding (the post-flood period).

\begin{tabular}{|c|c|c|c|c|c|c|}
\hline Site & $\begin{array}{c}\text { TVBC at } 37^{\circ} \mathrm{C} \times 10^{3} \\
\left(\mathrm{CFU} \mathrm{mL} \mathrm{mL}^{-1}\right)\end{array}$ & $\begin{array}{c}\text { TVBC at } 22{ }^{\circ} \mathrm{C} \times 10^{3} \\
\left(\mathrm{CFU} \mathrm{mL} \mathrm{mL}^{-1}\right)\end{array}$ & $\begin{array}{c}\text { TC } \\
\left(\mathrm{MPN} 100 \mathrm{~mL}^{-1}\right)\end{array}$ & $\begin{array}{c}\text { FC } \\
\left(\mathrm{MPN} 100 \mathrm{~mL}^{-1}\right)\end{array}$ & $\begin{array}{c}\text { FS } \\
\left(\mathrm{MPN} 100 \mathrm{~mL}^{-1}\right)\end{array}$ & $\begin{array}{c}\text { E. coli } \\
\left(\mathrm{CFU} 100 \mathrm{~mL}^{-1}\right)\end{array}$ \\
\hline 1 & 68 & 60 & 35 & 21 & 120 & 12 \\
\hline 2 & 85 & 80 & 460 & 460 & 290 & 250 \\
\hline 3 & 45 & 39 & 1100 & 1100 & 460 & 200 \\
\hline 4 & 29 & 50 & n.d. & n.d. & 43 & n.d. \\
\hline 5 & 25 & 66 & 16 & 16 & 23 & 9 \\
\hline 6 & 33 & 58 & 29 & 6 & 24 & n.d. \\
\hline 7 & 110 & 102 & 29 & 15 & 5 & 9 \\
\hline 8 & 22 & 29 & 53 & 24 & 14 & 8 \\
\hline 9 & 46 & 75 & 16 & 16 & 20 & 5 \\
\hline 10 & 1.2 & 2 & 460 & 93 & 43 & 25 \\
\hline 11 & 4 & 8 & 11 & 7 & n.d. & n.d. \\
\hline 12 & 1 & 1.5 & n.d. & n.d. & 3 & n.d. \\
\hline 13 & 99 & 135 & 16 & 16 & 23 & 7 \\
\hline 14 & 50 & 95 & 15 & 7 & 7 & n.d. \\
\hline 15 & 66 & 75 & 23 & 23 & 4 & 10 \\
\hline Mean & 45.6 & 58.4 & 150.9 & 120.3 & 71.9 & 35.7 \\
\hline SD & 34.4 & 38.2 & 304.6 & 294.7 & 130.5 & 77.7 \\
\hline $\mathrm{CV}$ & 75.5 & 65.5 & 201.9 & 245.0 & 181.5 & 217.9 \\
\hline
\end{tabular}

TVBC—-total viable bacterial count, TC—-total coliforms, FC—fecal coliforms, FS—fecal streptococci, n.d.—not detected (zero), SDstandard deviation, CV—coefficient of variation, \%; sampling sites 1-15 concern five sectors and their eastern, middle and western parts, with detailed information in Table 1.

Table 4. Bacterial assessment of the main channel of Lake Nasser before flooding (the pre-flood period).

\begin{tabular}{|c|c|c|c|c|c|c|}
\hline Site & $\begin{array}{l}\text { TVBC at } 37^{\circ} \mathrm{C} \times 10^{3} \\
\quad\left(\mathrm{CFU} \mathrm{mL}^{-1}\right)\end{array}$ & $\begin{array}{l}\text { TVBC at } 22{ }^{\circ} \mathrm{C} \times 10^{3} \\
\left(\text { CFU } \mathrm{mL}^{-1}\right)\end{array}$ & $\begin{array}{c}\text { TC } \\
\left(\mathrm{MPN} 100 \mathrm{~mL}^{-1}\right)\end{array}$ & $\begin{array}{c}\text { FC } \\
\left(\mathrm{MPN} 100 \mathrm{~mL}^{-1}\right)\end{array}$ & $\begin{array}{c}\text { FS } \\
\left(\mathrm{MPN} 100 \mathrm{~mL}^{-1}\right)\end{array}$ & $\begin{array}{c}\text { E. coli } \\
\left(\mathrm{CFU} 100 \mathrm{~mL}^{-1}\right)\end{array}$ \\
\hline 1 & 16 & 11 & 93 & 7 & 4 & n.d. \\
\hline 2 & 12 & 10 & 9 & 4 & n.d. & n.d. \\
\hline 3 & 24 & 18 & 43 & 9 & n.d. & n.d. \\
\hline 4 & 12 & 10 & 9 & n.d. & n.d. & n.d. \\
\hline 5 & 1.6 & 1.3 & 4 & n.d. & 9 & n.d. \\
\hline 6 & 21 & 24 & 21 & n.d. & 9 & n.d. \\
\hline 7 & 18 & 16 & 15 & 4 & 240 & n.d. \\
\hline 8 & 29 & 23 & 4 & 4 & 4 & n.d. \\
\hline 9 & 25 & 34 & 150 & 23 & n.d. & 12 \\
\hline 10 & 32 & 28 & 46,000 & 240 & 23 & 150 \\
\hline 11 & 0.9 & 0.8 & 460 & 93 & 460 & 46 \\
\hline 12 & 19 & 22 & 1100 & 43 & 4 & 22 \\
\hline 13 & 12 & 10 & 46,000 & 150 & 93 & 90 \\
\hline 14 & 1.9 & 21 & 460 & 43 & n.d. & 25 \\
\hline 15 & 16 & 21 & 46,000 & 150 & 460 & 95 \\
\hline Mean & 16.0 & 16.7 & 9357.9 & 51.3 & 87.1 & 29.3 \\
\hline SD & 9.6 & 9.4 & $18,966.4$ & 73.7 & 164.0 & 46.4 \\
\hline $\mathrm{CV}$ & 59.9 & 56.5 & 202.7 & 143.7 & 188.3 & 158.0 \\
\hline
\end{tabular}

TVBC — total viable bacterial count, TC—-total coliforms, FC—fecal coliforms, FS—fecal streptococci, n.d.—not detected (zero), SD— standard deviation, CV-coefficient of variation, \%; sampling sites 1-15 concern five sectors and their eastern, middle and western parts, with detailed information in Table 1.

The TC bacteria were more abundant after flooding, and their numbers fluctuated between 0 and $1100 \mathrm{MPN} 100 \mathrm{~mL}^{-1}$, whereas before flooding-between 4 and 46,000 MPN $100 \mathrm{~mL}^{-1}$. On the contrary, FC numbers at Lake Nasser were in the range of 0-1100 MPN $100 \mathrm{~mL}^{-1}$ and 0-240 MPN $100 \mathrm{~mL}^{-1}$ in the post- and pre-flood periods, respectively.

The numbers of FS in both periods were similar and ranged within 0-460 MPN $100 \mathrm{~mL}^{-1}$. The numbers of Escherichia coli, in turn, fluctuated between 0 and $250 \mathrm{CFU}$ $100 \mathrm{~mL}^{-1}$ and between 0 and $150 \mathrm{CFU} 100 \mathrm{~mL}^{-1}$ after and before flooding, respectively.

\subsection{Phytoplankton}

Generally, the phytoplankton assemblages of Lake Nasser comprised eight phyla: Cyanobacteria, Bacillariophyta, Charophyta (planktonic), Chlorophyta, Cryptophyta, Euglenozoa, Miozoa and Ochrophyta. Their total density ranged from 0.7 to $7.6 \times 10^{6}$ cells $^{-1}$ in the post-flood period (Figure 2A). The highest density was found at site M5W. In the pre- 
flood period, the total density changed in a wider range, i.e., from 2.2 to $27.3 \times 10^{6}$ cells L $^{-1}$ (Figure 2B). In this period, the densities at sites 1-6 were similar, but the values at other sites were over two times higher than in the post-flood period. Maximally, the values were 35 and 31 times higher at sites 13 and 15, respectively. The structure of phytoplankton was similar in both periods. The assemblages were usually dominated by Cyanobacteria which formed $36-95 \%$ and $71-98 \%$ of the total density in the post-flood and pre-flood periods, respectively. The second important group was Chlorophyta with the shares of $4-40 \%$ and $0-23 \%$, respectively. Only in the post-flood period, Bacillariophyta maximally reached $21 \%$ (site 13).

Concerning biodiversity, species richness of phytoplankton was usually higher (20-46 species) in the pre-flood period and amounted to approximately 31 species (Table 5). However, the values of the Shannon index and evenness were higher in the post-flood period (1.770 and 0.543 on average) than in the pre-flood period (1.513 and 0.439 on average).

The highest density was found for Chroococcus minimus (15-83\% of the total density) and Pseudanabaena sp. (1-44\%) in the post-flood period (Table 6). Merismopedia tenuissima, Desmococcus olivaceus and Aulacoseira granulata also had relatively high shares at selected sites. In the pre-flood period, Chroococcus minutus (up to $69 \%$ at site 7 ), Ch. minimus (up to $76 \%$ at site 11), Spirulina laxa (up to $76 \%$ at site 13 ) and Merismopedia punctata (up to $16 \%$ at site 4) were the most abundant.

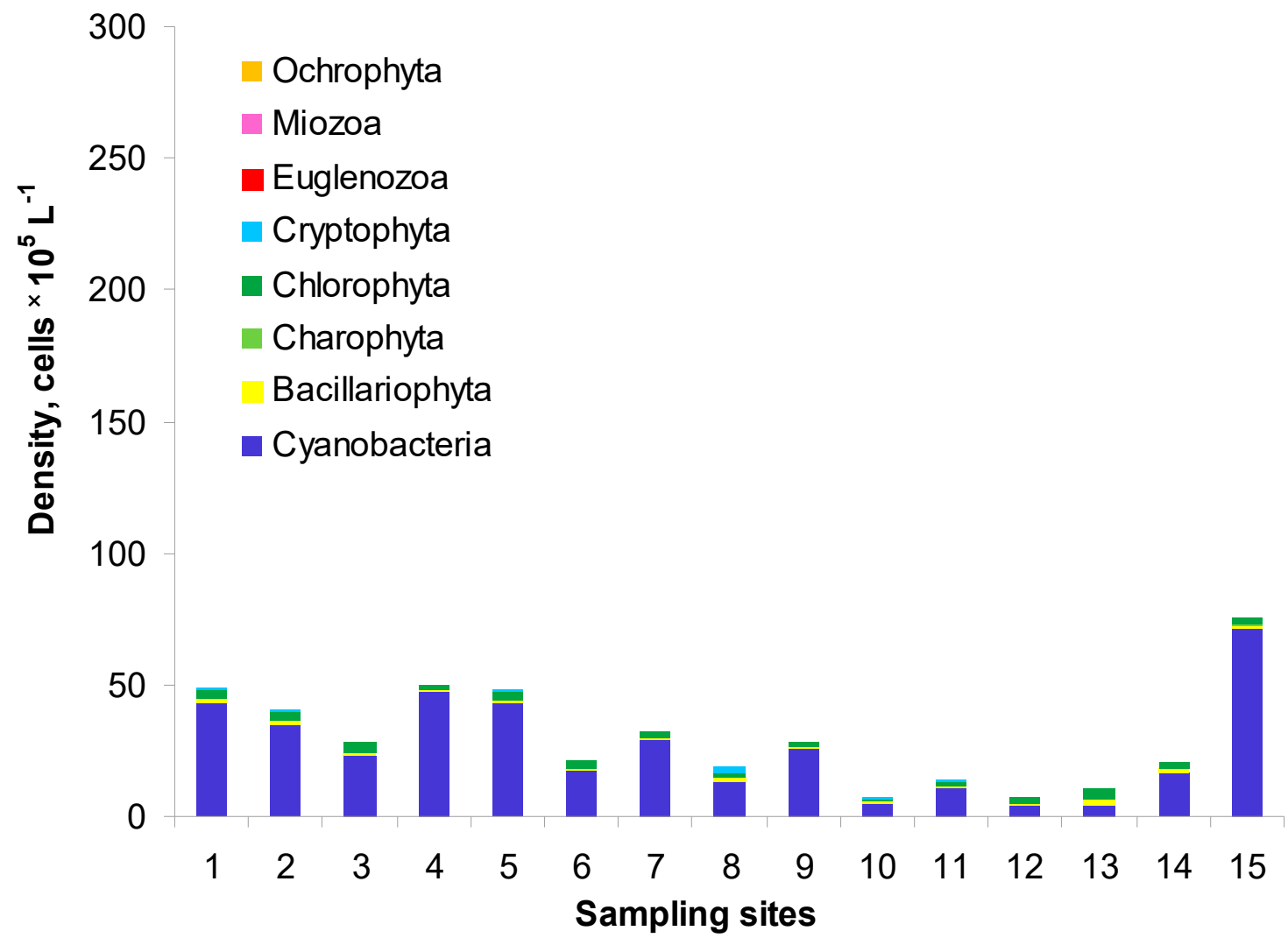

(A)

Figure 2. Cont. 


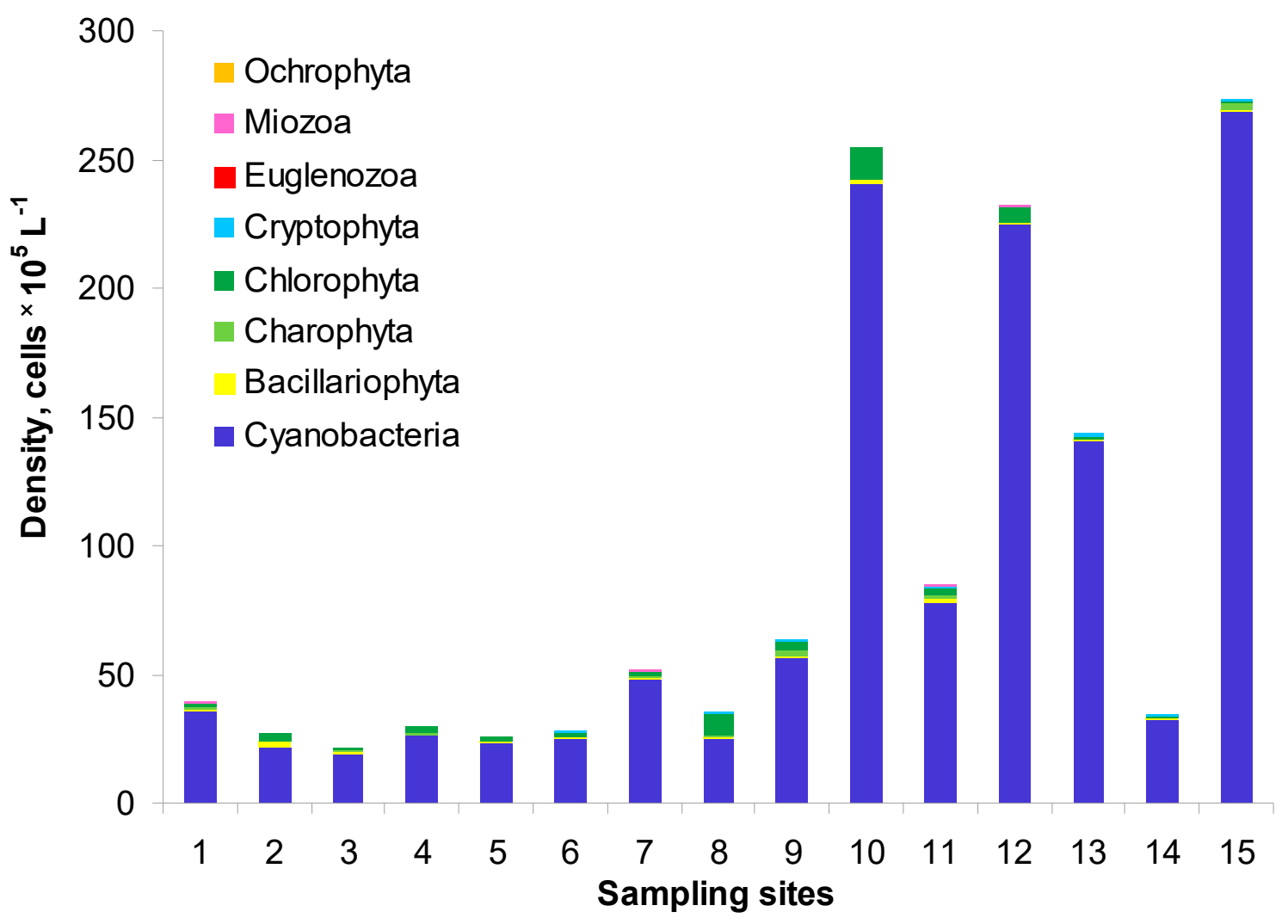

(B)

Figure 2. Phytoplankton density and structure in the post-flood period (A) and the pre-flood period (B) in the main channel of Lake Nasser; sampling sites 1-15 concern five sectors and their eastern, middle and western parts, with detailed information in Table 1.

Table 5. Species richness and biodiversity of phytoplankton in Lake Nasser in the post-flood and pre-flood periods.

\begin{tabular}{|c|c|c|c|c|c|c|}
\hline \multirow{2}{*}{ Site } & \multicolumn{2}{|c|}{ Species Richness (SR) } & \multicolumn{2}{|c|}{ Shannon Index (SI) } & \multicolumn{2}{|c|}{ Evenness (E) } \\
\hline & Post-Flood & Pre-Flood & Post-Flood & Pre-Flood & Post-Flood & Pre-Flood \\
\hline 1 & 39 & 38 & 2.007 & 1.859 & 0.548 & 0.511 \\
\hline 2 & 33 & 46 & 1.817 & 2.533 & 0.520 & 0.662 \\
\hline 3 & 27 & 29 & 1.691 & 1.694 & 0.513 & 0.503 \\
\hline 4 & 28 & 30 & 1.221 & 1.877 & 0.366 & 0.552 \\
\hline 5 & 32 & 41 & 1.700 & 1.914 & 0.491 & 0.515 \\
\hline 6 & 38 & 42 & 1.986 & 2.041 & 0.546 & 0.546 \\
\hline 7 & 28 & 32 & 1.392 & 1.259 & 0.418 & 0.363 \\
\hline 8 & 25 & 29 & 2.031 & 1.761 & 0.631 & 0.523 \\
\hline 9 & 25 & 31 & 1.699 & 1.635 & 0.528 & 0.476 \\
\hline 10 & 25 & 29 & 2.179 & 1.196 & 0.677 & 0.355 \\
\hline 11 & 24 & 30 & 1.887 & 1.154 & 0.594 & 0.339 \\
\hline 12 & 24 & 27 & 2.308 & 1.026 & 0.726 & 0.311 \\
\hline 13 & 15 & 20 & 2.113 & 0.864 & 0.780 & 0.289 \\
\hline 14 & 26 & 20 & 1.813 & 1.270 & 0.556 & 0.424 \\
\hline 15 & 41 & 26 & 0.944 & 0.955 & 0.254 & 0.293 \\
\hline Mean & 27.9 & 30.9 & 1.770 & 1.513 & 0.543 & 0.439 \\
\hline SD & 6.5 & 7.6 & 0.377 & 0.484 & 0.139 & 0.116 \\
\hline $\mathrm{CV}$ & 23.1 & 24.5 & 21.3 & 32.0 & 25.7 & 26.4 \\
\hline
\end{tabular}

SD—standard deviation, CV—coefficient of variation, \%, sampling sites 1-15 concern five sectors and their eastern, middle and western parts, with detailed information in Table 1. 
Table 6. Dominant phytoplankton species (relative density, \%) in the post- and pre-flood periods at sites 1-15.

\begin{tabular}{|c|c|c|c|c|c|c|c|c|c|c|c|c|c|c|c|}
\hline \multirow{3}{*}{ Species } & \multicolumn{15}{|c|}{ Sampling SITES } \\
\hline & 1 & 2 & 3 & 4 & 5 & 6 & 7 & 8 & 9 & 10 & 11 & 12 & 13 & 14 & 15 \\
\hline & \multicolumn{15}{|c|}{ Post-Flood Period } \\
\hline Chroococcus dispersus & 5 & 4 & 0 & 3 & 1 & 2 & 3 & 0 & 0 & 4 & 0 & 2 & 0 & 2 & 0 \\
\hline Chroococcus minimus & 21 & 55 & 42 & 65 & 49 & 42 & 67 & 48 & 46 & 30 & 49 & 34 & 16 & 53 & 83 \\
\hline Coelosphaerium dubium & 2 & 0 & 0 & 3 & 0 & 0 & 0 & 0 & 0 & 0 & 0 & 11 & 0 & 7 & 4 \\
\hline Raphidiopsis raciborskii & 0 & 0 & 4 & 1 & 2 & 3 & 1 & 5 & 2 & 3 & 2 & 0 & 7 & 2 & 0 \\
\hline Merismopedia tenuissima & 7 & 2 & 0 & 1 & 10 & 0 & 4 & 10 & 6 & 0 & 11 & 0 & 0 & 0 & 2 \\
\hline Aphanocapsa incerta & 0 & 9 & 0 & 0 & 0 & 0 & 0 & 0 & 21 & 0 & 0 & 0 & 0 & 0 & 0 \\
\hline Pseudanabaena sp. & 44 & 10 & 34 & 21 & 24 & 27 & 13 & 6 & 14 & 28 & 14 & 7 & 13 & 11 & 1 \\
\hline Coelastrum cambricum & 2 & 0 & 3 & 0 & 2 & 2 & 1 & 0 & 3 & 0 & 0 & 0 & 5 & 0 & 0 \\
\hline Coelastrum microporum & 0 & 0 & 0 & 0 & 2 & 0 & 2 & 0 & 0 & 0 & 0 & 0 & 10 & 0 & 0 \\
\hline Monactinus simplex & 0 & 0 & 0 & 0 & 0 & 0 & 1 & 0 & 0 & 4 & 2 & 11 & 0 & 2 & 0 \\
\hline Desmococcus olivaceus & 0 & 0 & 3 & 0 & 1 & 3 & 1 & 0 & 1 & 2 & 5 & 6 & 23 & 8 & 0 \\
\hline Aulacoseira granulata & 0 & 0 & 0 & 0 & 0 & 0 & 1 & 1 & 0 & 9 & 5 & 9 & 17 & 5 & 0 \\
\hline Pantocsekiella ocellata & 2 & 2 & 2 & 1 & 1 & 1 & 2 & 5 & 3 & 2 & 0 & 0 & 0 & 0 & 0 \\
\hline Melosira sp. & 0 & 0 & 0 & 0 & 0 & 0 & 0 & 0 & 0 & 5 & 2 & 3 & 3 & 1 & 0 \\
\hline \multirow[t]{2}{*}{ Cryptomonas erosa } & 0 & 0 & 0 & 0 & 0 & 0 & 0 & 9 & 0 & 2 & 1 & 1 & 1 & 1 & 0 \\
\hline & \multicolumn{15}{|c|}{ Pre-Flood Period } \\
\hline Chroococcus dispersus & 0 & 0 & 0 & 5 & 1 & 0 & 0 & 0 & 0 & 0 & 0 & 0 & 0 & 0 & 0 \\
\hline Chroococcus minimus & 4 & 6 & 12 & 2 & 9 & 6 & 4 & 0 & 2 & 3 & 76 & 34 & 0 & 0 & 0 \\
\hline Chroococcus minutus & 47 & 32 & 54 & 43 & 38 & 35 & 69 & 35 & 54 & 47 & 0 & 0 & 17 & 21 & 31 \\
\hline Coelosphaerium kuetzingianum & 0 & 5 & 0 & 0 & 0 & 0 & 0 & 0 & 0 & 0 & 0 & 0 & 0 & 0 & 0 \\
\hline Raphidiopsis raciborskii & 0 & 7 & 0 & 0 & 0 & 0 & 0 & 0 & 0 & 0 & 4 & 0 & 0 & 0 & 0 \\
\hline Merismopedia punctata & 10 & 4 & 6 & 16 & 6 & 11 & 5 & 6 & 5 & 1 & 4 & 2 & 2 & 4 & 1 \\
\hline Microcystis aeruginosa f. aeruginosa & 4 & 6 & 0 & 2 & 1 & 0 & 1 & 1 & 2 & 1 & 1 & 0 & 1 & 0 & 0 \\
\hline Oscillatoria limosa & 0 & 0 & 0 & 0 & 14 & 0 & 0 & 0 & 0 & 0 & 0 & 1 & 0 & 0 & 0 \\
\hline Spirulina laxa & 20 & 16 & 14 & 18 & 23 & 29 & 14 & 28 & 24 & 41 & 0 & 59 & 76 & 62 & 63 \\
\hline Chlamydomonas globosa & 0 & 5 & 0 & 5 & 0 & 0 & 0 & 0 & 0 & 0 & 0 & 2 & 0 & 0 & 0 \\
\hline Coelastrum microporum & 1 & 2 & 3 & 0 & 1 & 1 & 0 & 21 & 3 & 4 & 1 & 0 & 0 & 0 & 0 \\
\hline
\end{tabular}

\subsection{Zooplankton}

The total density of zooplankton ranged from 0.2 to $4.2 \times 10^{4}$ organism $\mathrm{m}^{-3}$ in the post-flood period (Figure 3A). The highest densities (approximately $4.1 \times 10^{4}$ org. $\mathrm{m}^{-3}$ ) were found at sites 1, 3 and 6 . A high value was also recorded at site 2 . In the pre-flood period, the total density was generally lower and ranged within $0.1-2.7 \times 10^{4}$ org. $\mathrm{m}^{-3}$ (Figure 3B). Significant differences, i.e., about 2-26 times lower values, were found at ten sites. In other cases, the values were similar or even higher at sites 5, 10 and 11 in the pre-flood period than in the post-flood period. The relations in the zooplankton structure were as follows: Copepoda > Cladocera $>$ Rotifera in both study periods. In the postflood period, the average share of these groups in the total density amounted to $83 \%$, $10 \%$ and $7 \%$, respectively, whereas in the pre-flood period, it amounted to $63 \%, 26 \%$ and $11 \%$, respectively.

Three adult species of Copepoda, seven species of Cladocera and ten species of Rotifera were recorded. Copepoda was represented primarily by Thermodiaptomus galebi, Mesocyclops ogunnus, and nauplius larvae (Supplementary Table S1). In the post-flood period, the highest copepod density was recorded at site 1, whereas the lowest density-at site 11. On the contrary, in the pre-flood period, the maximum was at site 10 (also in the Tushka sector), the minimum—at site 1 (the HD upstream sector). Generally, higher copepod density was usually recorded in the post-flood period.

In the Cladocera community, Diaphanosoma mongolianum and Ceriodaphnia reticulata were dominants in both periods, although with high variation at sampling sites. Bosmina longirostris had high densities at sites 10-15 (with the maximum of $80 \%$ of the total density) in the post-flood period. On the other hand, Alona intermedia was found only in the postflood period at sites 1-7 with the maximum of $19 \%$ (site 1). Generally, higher cladoceran densities (over 5000 org. $\mathrm{m}^{-3}$ ) were noted at sites 6, 12 and 15, lower-at sites 13 and 14 . 
In temporal comparison, higher densities were usually noted at sites 1, 2, 3, 4, 6, 7 and 15 in the post-flood period, and at the other sites in the pre-flood period.

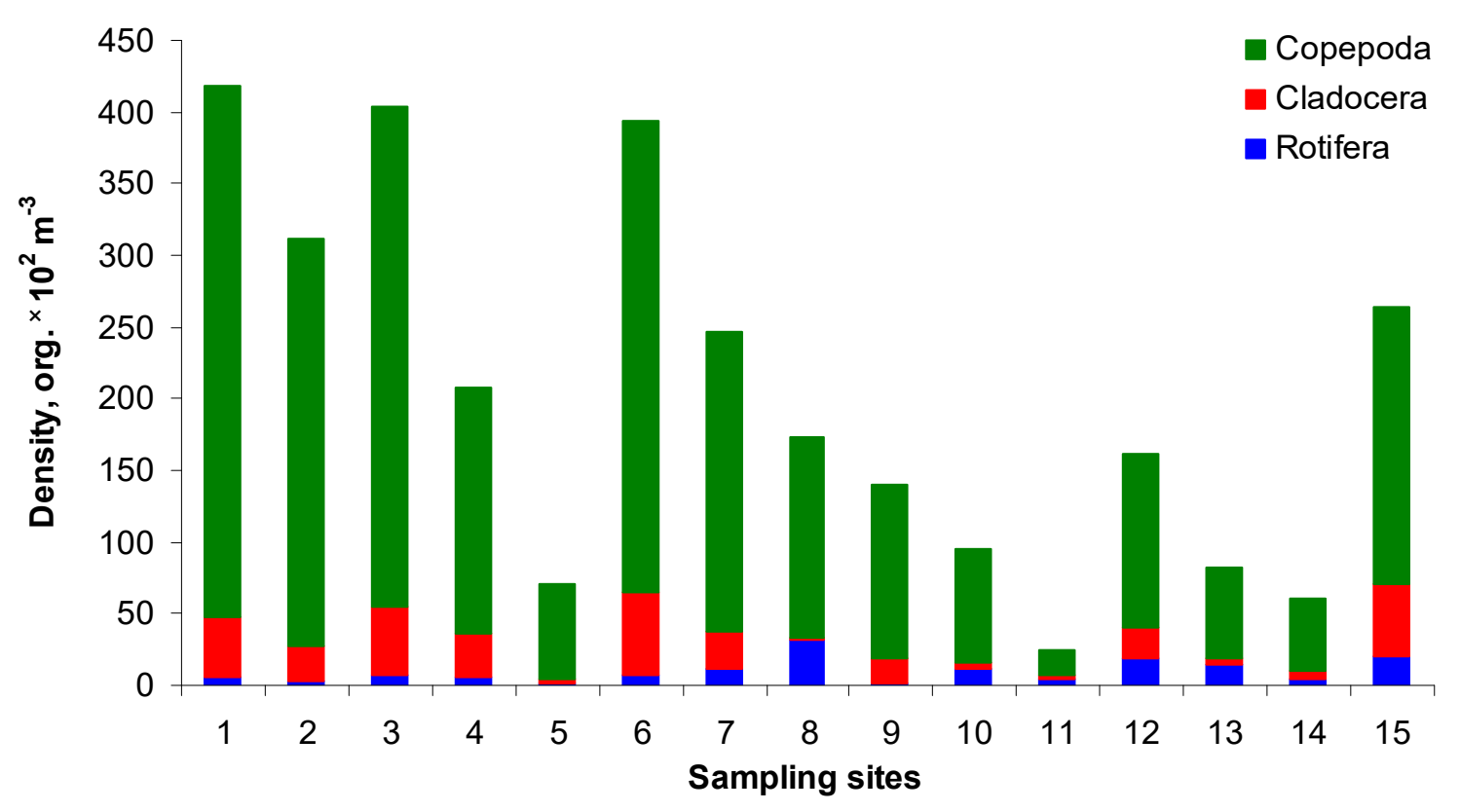

(A)

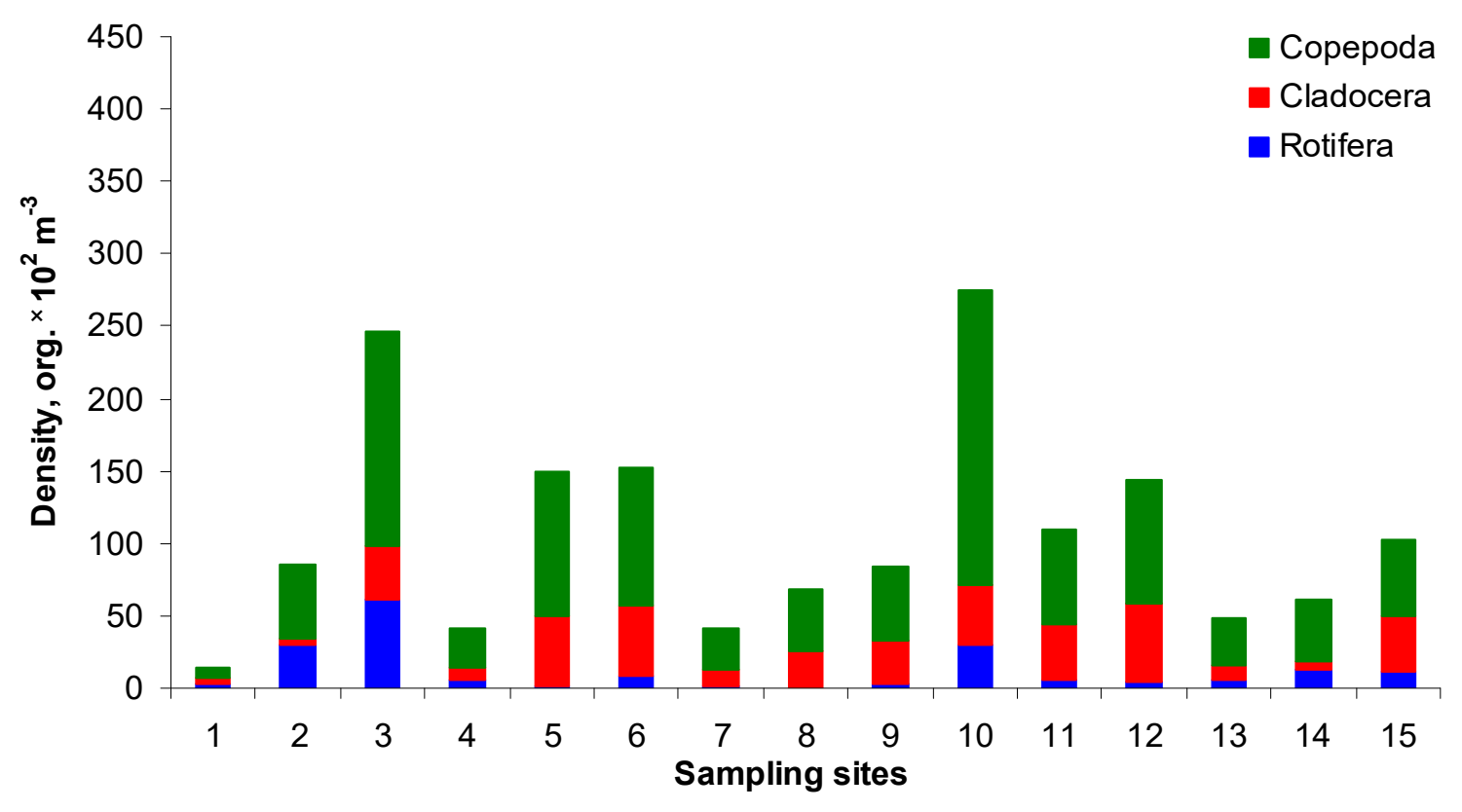

(B)

Figure 3. Zooplankton density and structure in the post-flood period (A) and the pre-flood period (B) in the main channel of Lake Nasser; sampling sites 1-15 concern five sectors and their eastern, middle and western parts, with detailed information in Table 1.

Compared to other zooplankton groups, Rotifera occurred in the lowest density, with the maximum at site 3 (over $6000 \mathrm{org} . \mathrm{m}^{-3}$ ) and the minimum at site 8 (lack of rotifers in the pre-flood period). Their densities were higher in the post-flood period at sites 1,5, $7,8,12,13,15$ and at the other sites in the pre-flood period. However, Rotifera were more abundant in June 2020 on average. Keratella cochlearis, Keratella quadrata, Keratella tropica, Brachionus calyciflorus and Asplanchna sp. were the most often and abundantly recorded 
in the post-flood period. On the other hand, Polyarthra vulgaris and Lecane lunaris were recorded only in November 2019.

\subsection{Planktonic Organisms and Physicochemical Parameters-Relations within and between}

Regarding the biotic variables, the analysis using NMDS with the stress value of 0.050578 allowed separating the samples taken in the post-flood period from the samples taken in the pre-flood period (Figure 4). The first group of samples was dominated by phytoplankton (total and its main representative groups), TC, FS and E. coli. However, the strongest relations were for the samples from sites 10,12,13 and 15. The samples taken in the pre-flood period created the second group dominated primarily by total zooplankton and its main groups, TVBC and FC.

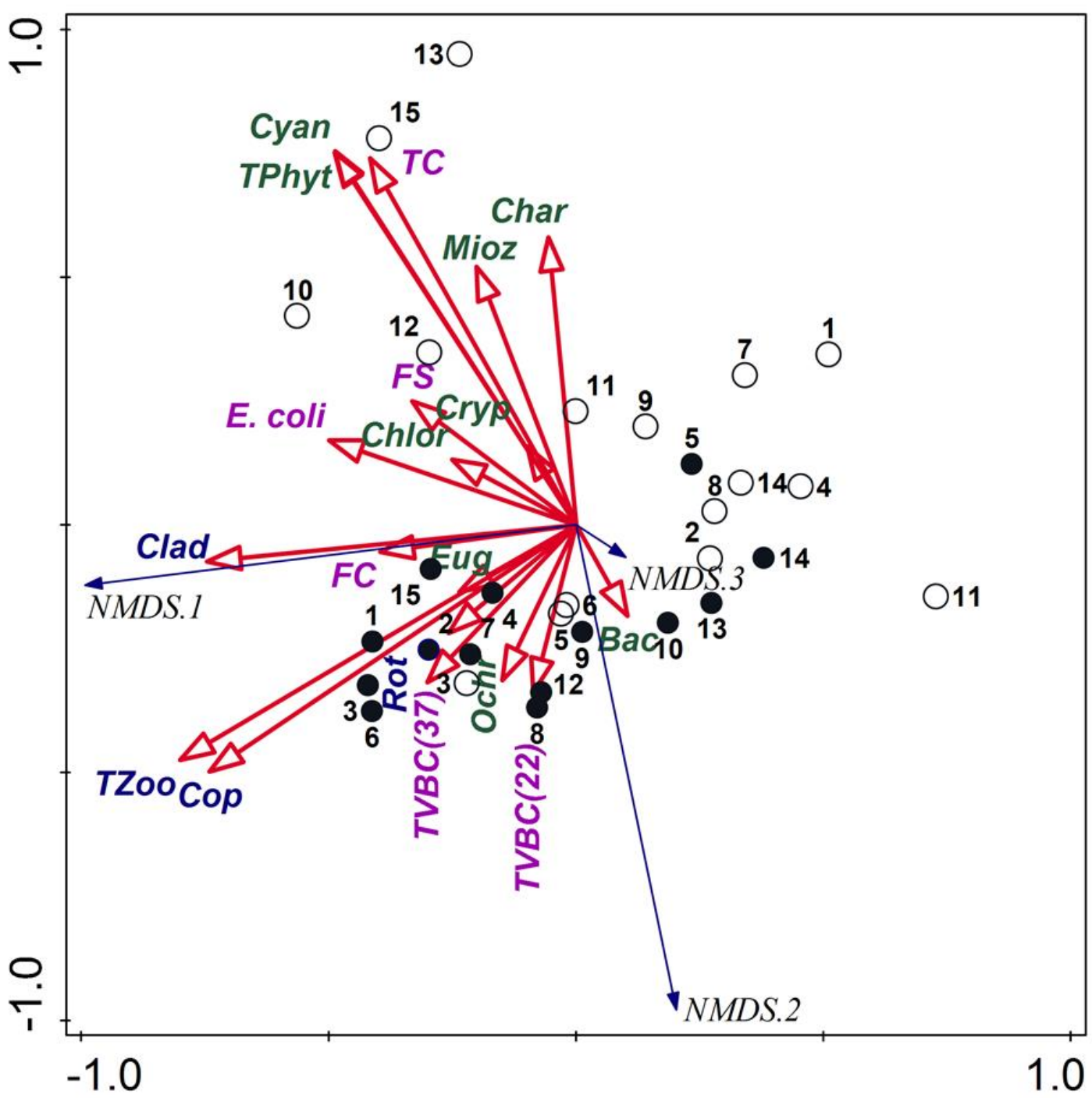

Figure 4. NMDS triplot based on planktonic organisms; empty circles-samples from the post-flood period, black circles—samples from the pre-flood period; codes of plankton: TPhyt-total phytoplankton, Cyan-Cyanobacteria, Char-Charophyta, Mioz-Miozoa, Cryp-Cryptophyta, Chlor-Chlorophyta, Eug-Euglenozoa, Ochr-Ochrophyta, Bac-Bacillariophyta, TZoo-total zooplankton, Clad-Cladocera, Cop-Copepoda, Rot-Rotifera, TVBC-total viable bacterial count, TC — total coliforms, FC—fecal coliform, FS-fecal streptococci.

On the other hand, the NMDS analysis with the stress value of 0.044735 concerning the physicochemical parameters also allowed distinguishing two separate groups of samples (Figure 5). The first one covered the samples taken in the pre-flood period, and the most 
influenced factors were T, TSS, $\mathrm{pH}, \mathrm{Cl}, \mathrm{Mg}, \mathrm{PO}_{4}, \mathrm{~K}, \mathrm{Na}, \mathrm{Ca}, \mathrm{CO}_{3}, \mathrm{Chl}-a$ and $\mathrm{SO}_{4}$. The second group was created by the samples taken in the post-flood period with the following main influencing factors: $\mathrm{HCO}_{3}, \mathrm{SiO}_{4}, \mathrm{EC}$, TDS, TS. The samples taken at sites 13 and 15 were the most connected primarily with mineral forms of nitrogen and $\mathrm{DO}$, and they were separated from the second group.

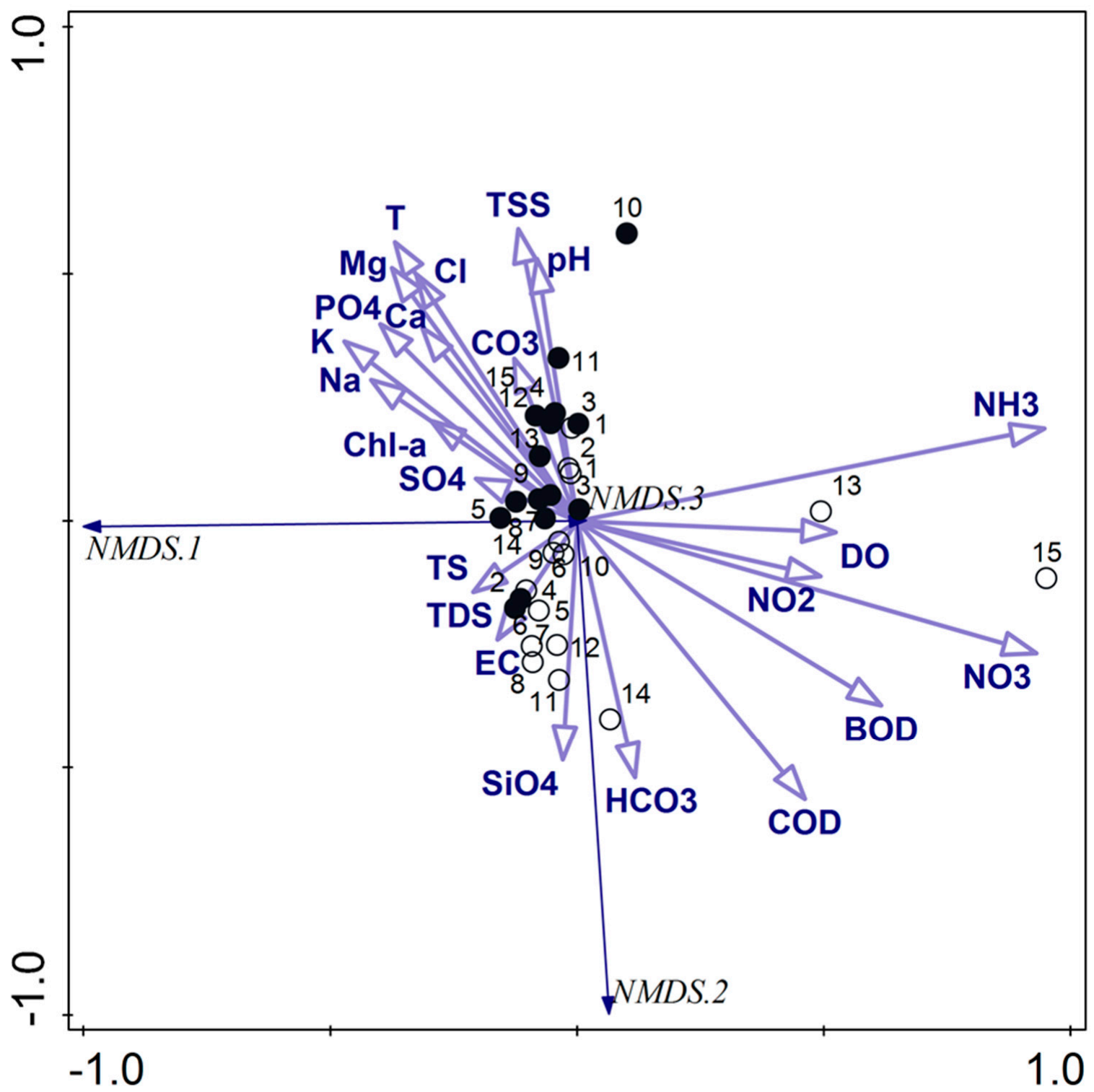

Figure 5. NMDS triplot based on the physicochemical parameters; empty circles—samples from the post-flood period, black circles_-samples from the pre-flood period; codes of the physicochemical parameters are explained in the Materials and Methods (including $\mathrm{PO} 4-\mathrm{PO}_{4}, \mathrm{CO} 3-\mathrm{CO}_{3}, \mathrm{SO} 4-\mathrm{SO}_{4}, \mathrm{SiO} 4-\mathrm{SiO}_{4}, \mathrm{NH}-\mathrm{NH}_{3}, \mathrm{NO} 3-\mathrm{NO}_{3}, \mathrm{NO}_{2}-\mathrm{NO}_{2}, \mathrm{HCO}_{3}-\mathrm{HCO}_{3}$ ).

The relationships between planktonic and physicochemical parameters were analyzed with RDA ordination. The total variation was 991.33206, and the explanatory variables accounted for $58.7 \%$. The sum of all the canonical eigenvalues was 0.5866 . The two axes of response data in the RDA explained $46.6 \%$ of the total variance, where the first axis accounted for $34.9 \%$ whereas concerning the fitted response data it was $79.4 \%$ and $59.4 \%$, respectively. Strong correlations were found between total zooplankton, copepods, some groups of phytoplankton (Bacillariophyta, Ochrophyta, Euglenozoa and Chlorophyta), total viable bacterial counts and $\mathrm{Chl}-a, \mathrm{~T}, \mathrm{PO}_{4}, \mathrm{pH}$ (Figure 6). Such close relations related to the samples collected in the pre-flood period. On the other hand, strong correlations were 
found between total phytoplankton, Charophyta, Cyanobacteria, Miozoa, total coliform bacteria and mineral forms of nitrogen, COD and BOD. These relations were associated with a high similarity of samples taken in the post-flood period.

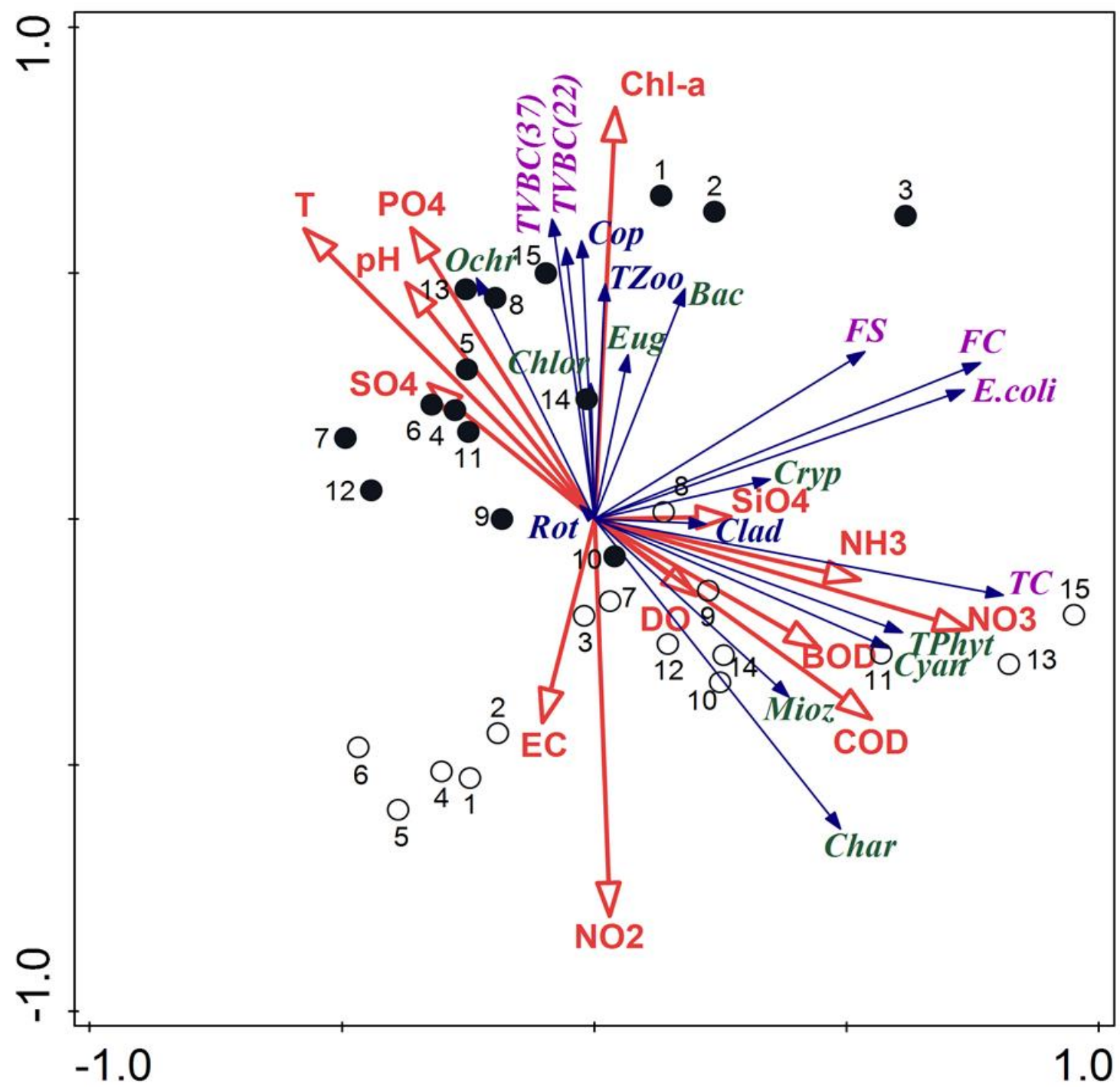

Figure 6. Triplot diagram of RDA of planktonic organisms and the main physicochemical parameters; empty circlessamples from the post-flood period, black circles—samples from the pre-flood period; codes of plankton are explained in Figure 4, codes of the physicochemical parameters are explained in the Materials and Methods (including $\mathrm{PO}_{4}-\mathrm{PO}_{4}$, $\mathrm{SO}_{4}-\mathrm{SO}_{4}, \mathrm{SiO} 4-\mathrm{SiO}_{4}, \mathrm{NH} 3-\mathrm{NH}_{3}, \mathrm{NO} 3-\mathrm{NO}_{3}, \mathrm{NO} 2-\mathrm{NO}_{2}$ ).

The results of Spearman's correlations were only in some cases in line with the RDA results. TVBC at $37^{\circ} \mathrm{C}$ and $22{ }^{\circ} \mathrm{C}$ positively and significantly correlated with Chl$a$ (correlation coefficients $\mathrm{R}=0.643$ and 0.606 , respectively). The bacterial counts also positively correlated with $\mathrm{T}$, TSS and $\mathrm{PO}_{4}(\mathrm{R}=0.424,0.434$ and 0.379 , respectively) and negatively with $\mathrm{NO}_{2}$ and $\mathrm{HCO}_{3}(\mathrm{R}=-0.683$ and -0.383 , respectively). Similarly, positive relations were observed for the Copepoda and total zooplankton density $(\mathrm{R}=0.513$ and 0.428 , respectively).

The total phytoplankton density was positively correlated with $\mathrm{COD}, \mathrm{T}, \mathrm{NO}_{3}$ $(\mathrm{R}=0.5173,0.432,0.434$, respectively $)$. Furthermore, strong relations were also found between $\mathrm{NO}_{3}$ and TC, E. coli and $\mathrm{FC}$, with $\mathrm{R}=0.491,0.431$ and 0.399 . 


\subsection{Macrophytes and Epiphytes}

Three macrophyte species related to different families were recorded throughout the study period: Myriophyllum spicatum, Potamogeton schweinfurthii and Najas marina subsp. armata, which belong to three families, Haloragaceae, Potamogetonaceae and Hydrocharitaceae, respectively.

Myriophyllum spicatum was the most dominant and present in $80 \%$ of the samples. P. schweinfurthii was recorded only in two samples (10\%), and N. marina subsp. armata-in one sample (5\%) (Table 7).

Table 7. Occurrence of the submerged macrophytes collected from Lake Nasser after (post-flood) and before (pre-flood) flooding.

\begin{tabular}{ccccccc}
\hline Sites & \multicolumn{2}{c}{ Myriophyllum spicatum } & \multicolumn{2}{c}{$\begin{array}{c}\text { Potamogeton } \\
\text { schweinfurthii }\end{array}$} & \multicolumn{2}{c}{$\begin{array}{c}\text { Najas marina subsp. } \\
\text { armata }\end{array}$} \\
\hline & Post-Flood & Pre-Flood & Post-Flood & Pre-Flood & Post-Flood & Pre-Flood \\
\hline 1 & + & + & - & - & - & - \\
3 & + & + & - & - & - & - \\
4 & + & - & - & + & - & - \\
6 & + & + & - & - & - & - \\
7 & + & + & + & - & - & - \\
9 & + & + & - & + & - & - \\
10 & - & + & - & - & + & - \\
12 & - & + & - & - & - & - \\
13 & - & + & - & - & - & - \\
15 & - & + & - & - & - & - \\
\hline
\end{tabular}

+ present; - absent; the sampling sites concern only the sites in sectors $1(1,3), 2(4,6), 3(7,9), 4(10,12)$ and $5(13$, 15) on the eastern and western banks, respectively, with detailed information in Table 1.

The total of 136 epiphytic species belonging to four classes were identified on the investigated macrophytes. Among them, 63 species belonged to Bacillariophyta, 41 speciesto Chlorophyta, 27 species - to Cyanobacteria, five species - to Miozoa. The total density of epiphytes ranged from 2.5 to $9.1 \times 10^{4}$ cells per $1 \mathrm{~g}$ of macrophytes in the post-flood period (Figure 7). Bacillariophyta had the highest share (62-76\%), followed by Chlorophyta (13-27\%), Cyanobacteria (5-12\%) and Miozoa (up to 5\%). In the pre-flood period, the density of epiphytes was from two to ten times higher than in the post-flood period, and it ranged from 6.9 to $45.2 \times 10^{4}$ cells per $1 \mathrm{~g}$ of macrophytes. The structure was also different, and the shares were as follows: $41-70 \%$-Bacillariophyta, $13-46 \%$-Chlorophyta, $8-25 \%$ - Cyanobacteria, up to $7 \%$-Miozoa.

\subsection{Fish}

The catches obtained with the investigated trammel nets in the lake khors were generally constituted of a low variety of species (Figure 8). The contribution of fish catch from khors in the total production of the lake did not vary between the seasons and studied sectors. Regarding the target species, the highest share had mango tilapias (Sarotherodon galilaeus, 52\%), Nile tilapias (Oreochromis niloticus, 19\%) and redbelly tilapias (Coptodon zillii, $9 \%$ ). In both khors, the investigated trammel nets showed a similar behavior towards the target species. They had the same catch efficiency. Regarding tilapias, trammel nets of different mesh sizes captured the same length classes in both areas, showing that selectivity of this species is not based on size differentiation, but only on the different catch efficiency of the various mesh sizes. 


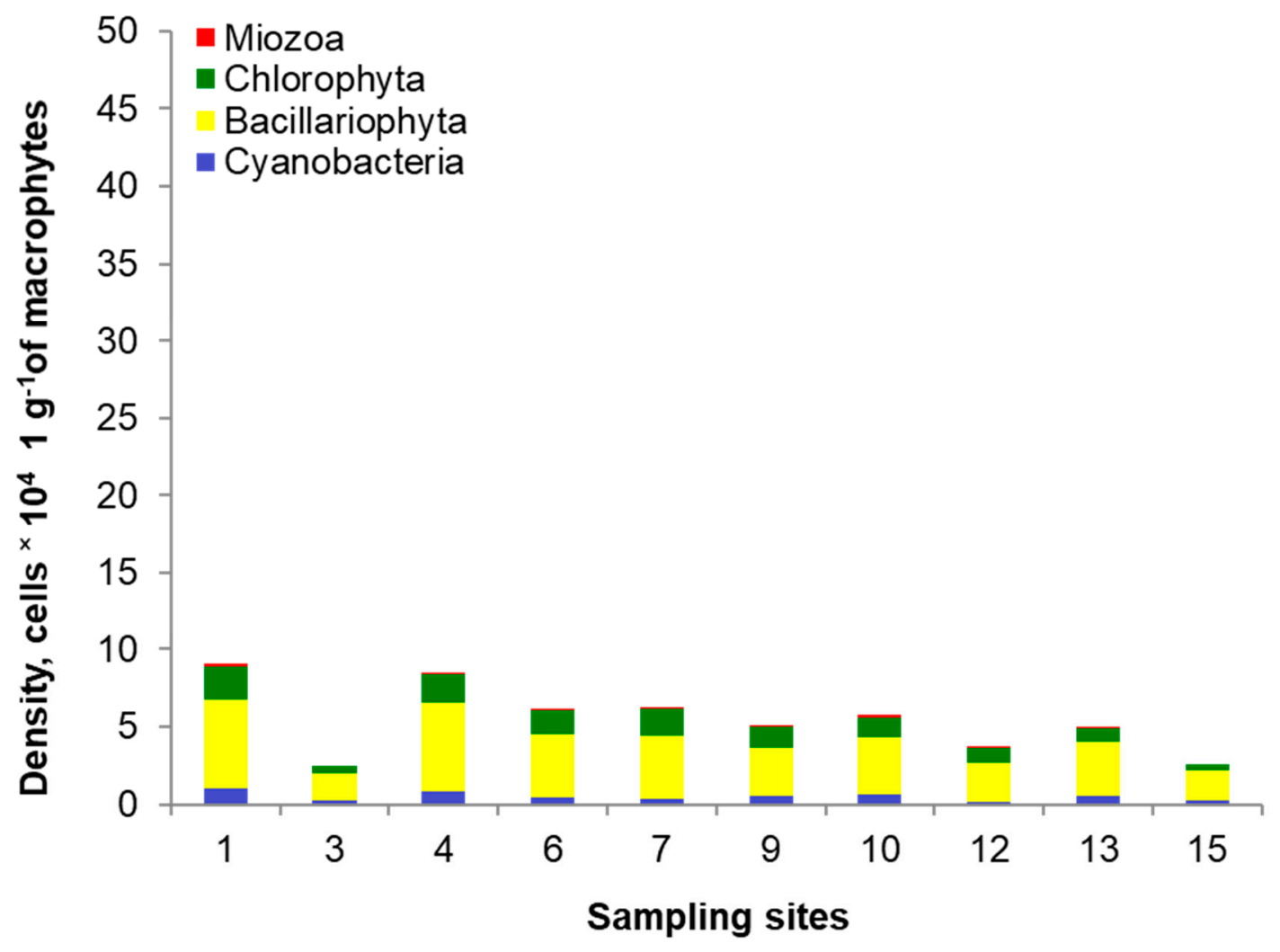

(A)

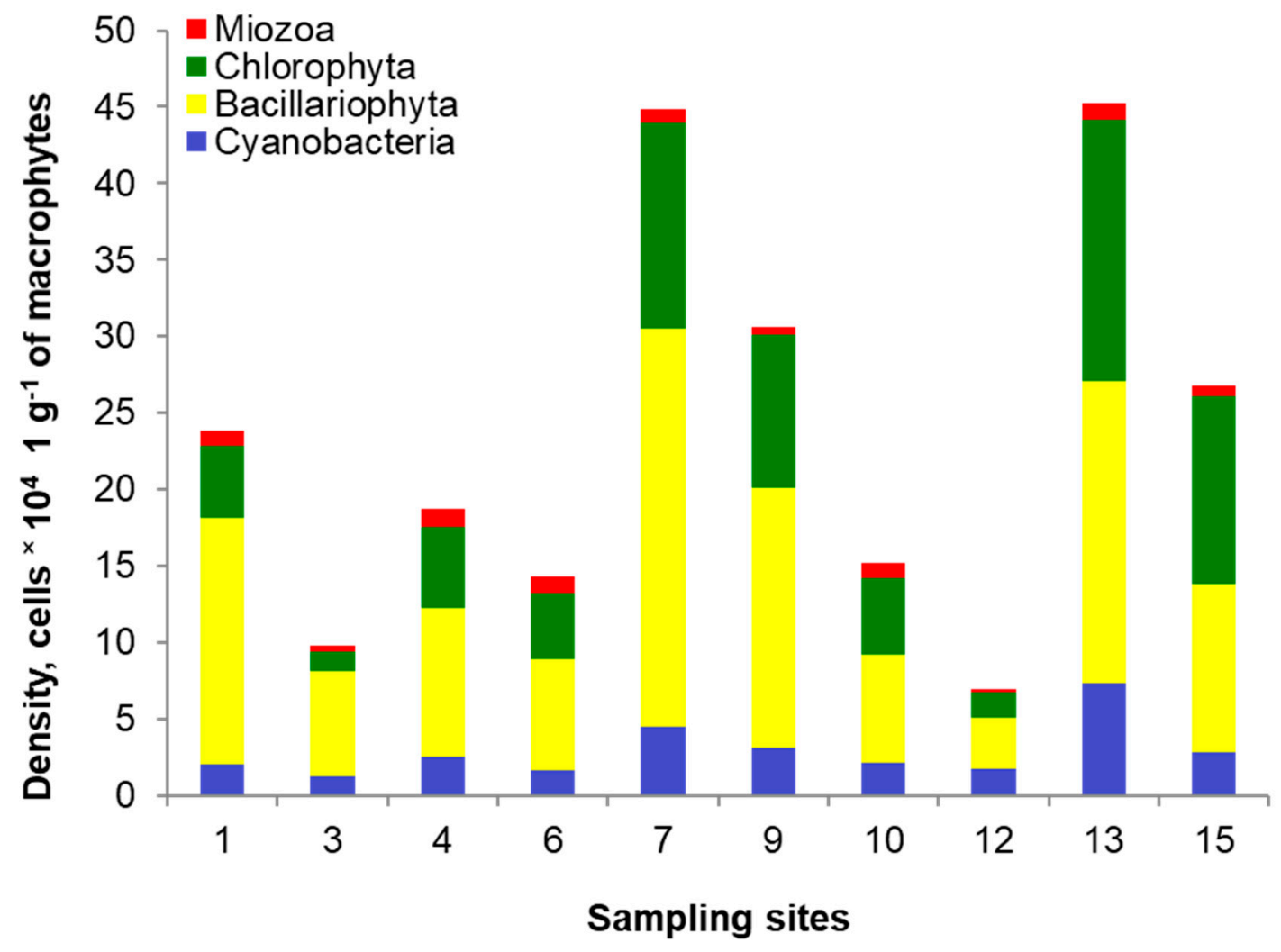

(B)

Figure 7. Epiphyte density and structure in the post-flood period (A) and the pre-flood period (B) in the main channel of Lake Nasser; the sampling sites concern only the sites in sectors $1(1,3), 2(4,6), 3(7,9), 4(10,12)$ and $5(13,15)$ on the eastern and western banks, respectively, with detailed information in Table 1. 


\section{FISH SPECIES COMPOSITION}

\section{- Coptodon zillii \\ Oreochromis niloticus \\ - Bagrus bajad \\ - Tetraodon lineatus \\ Mormyrus kannume \\ - Chrysichthys auratus}

\section{Sarotherodon galilaeus}

Synodontis serratus

- Malapterurus electricus

Lates niloticus

Synodontis clarias

- Chrysichthys auratus

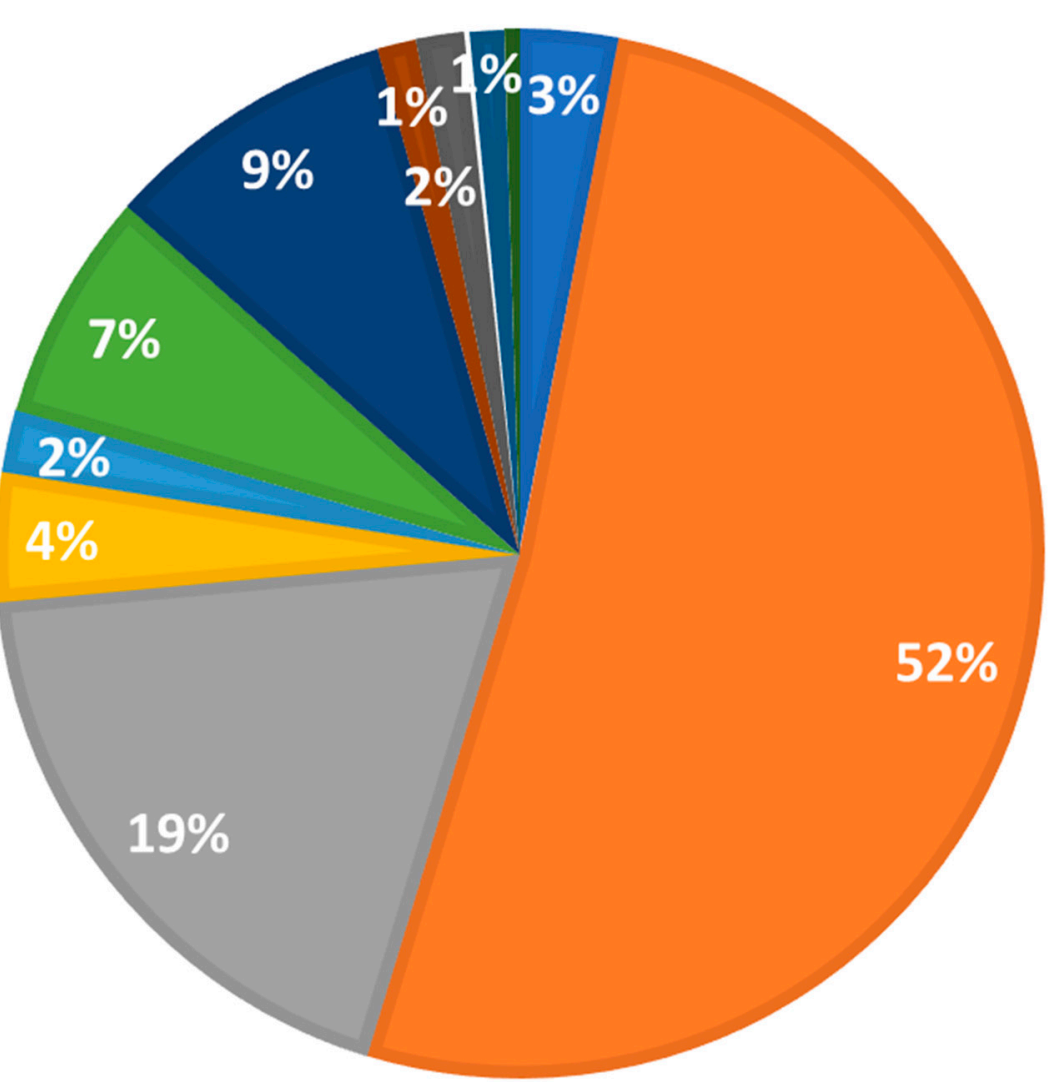

Figure 8. Species composition of the catches obtained with the trammel nets Ghazel El Shabar in Lake Nasser (percentages are by weight).

\section{Discussion}

Water quality can be assessed including aspects of the "quality for life" (e.g., the quality of the water needed for human consumption), "quality for food" (e.g., the quality of the water needed to sustain agricultural activities) or the "quality for nature" (e.g., the quality of the water needed to support thriving and diverse fauna and flora in the region). The selection of parameters used in the water quality assessment depends largely on the intended use of the water body [29]. Thus, water quality refers to the physical, chemical and biological characteristics of water in relation to the existence of life and especially human activity. It is predetermined by the intended uses and each of these uses affects, more or less, its quality [30]. In shallow lakes, the flooding season concerning the influence of 
extrinsic factors, including mainly the fertilizer loss through the runoff from farmlands [31], and intrinsic factors, i.e., sediment aggregations or floating materials [32], and other aspects such as hydrophyte uptake or decomposition [33] determine their quality.

The environment of Lake Nasser is favorable for biological processes in general and fish production because its $\mathrm{pH}$ values are always alkaline [34]. In the current studies, $\mathrm{pH}$ was 8.56 on average. Such $\mathrm{pH}$ value of the lake water lies within the optimum level for most freshwater fish species [35]. In the High Dam Lake, the higher $\mathrm{pH}$ values in the surface layers, with the general tendency to decrease with depth [3], have been attributed to intensive assimilation processes. The oxygen conditions (about $6.0 \mathrm{mg} \mathrm{L}^{-1}$ on average) were quite similar during both the post-flood and pre-flood periods. The lake's water showed narrow fluctuations of COD values between different seasons and localities. Moreover, low COD values due to the lack of organic matter and oxidizable breakdown materials were found in the water. The alkalinity was mostly due to bicarbonates, and the carbonate concentration was very limited.

In general, the physicochemical parameters in Lake Nasser water were within the acceptable criteria for drinking water according to the Egyptian drinking water quality standards (EWQS) [36], the USEPA [37] and the WHO [38]; for irrigation water according to the FAO [39]; and for the life of aquatic organisms according to standards of the CCME [40]. This all reflects the good quality of the lake water and its suitability for different purposes.

Concerning nutrient conditions, phosphates were in relatively low concentrations, however, significantly higher in the pre-flood period. The concentrations of nitrites and nitrates were, on the contrary, higher in the post-flood period. The effect of these nutrient conditions was revealed in the higher chlorophyll $a$ content (up to $102.4 \mu \mathrm{g} \mathrm{L}^{-1}$ ) and the higher zooplankton density in the post-flood period. However, the phytoplankton density was generally lower at this time. Ammonium-nitrogen was at the same level in both periods, especially at the selected sites of the Tushka and Abu Simble regions. Similarly, the higher phytoplankton density and total coliform bacteria but lower zooplankton density were found at these sites (i.e., sites 10-15). The comprehensive study of environment of Lake Nasser before operating the Renaissance Dam indicated regional variations in all of the parameters. The previous studies also confirmed such differentiations [41,42]. The phytoplankton did not reach a stable state in the lake after the construction of the High Dam. It was strongly dependent on the physicochemical factors regulated with floodwaters. The future negative changes in water quality, water level, soil salinity after water storing in the Grand Ethiopian Renaissance Dam are expected in Lake Nasser and the surrounding area $([43,44]$ and the references therein). However, future studies on the effects, impacts and changes are highly recommended.

Freshwater lakes are important habitats for diverse microbial communities [45]. Results of bacterial assessment referring to TVBC in the post-flood and pre-flood periods differed highly by sample origin. Mean TVBCs were significantly influenced by the temperature of incubation (i.e., TVBCs at $22^{\circ} \mathrm{C}>\mathrm{TVBC}$ at $37^{\circ} \mathrm{C}$ ). Coliforms were internationally recognized in the assessing of the microbiological water quality, and currently, total coliforms, fecal coliforms and Enterococcus spp. are used as microbial indicators for predicting water pollution [46]. In Lake Nasser, FC, FS and E. coli had high numbers in the post-flood period at sites 2 and 3. During the pre-flood period, the highest numbers of TC bacteria of up to $460 \times 10^{2} \mathrm{MPN} 100 \mathrm{~mL}^{-1}$ were recorded at sites 10,13 and 15 , while the FC bacteria had high values at sites 10 and 15, the FS bacteria-at sites 7,10 and 15 . The high values of bacterial indicators at the selected sites of Lake Nasser might be related to human activities such as the use of fishing boats and cruise ships.

Dense phytoplankton in the pre-flood period seems to be due to (1) the increase of sunlight (intensity and time), (2) the relative increase of water temperature (that enhances all phytoplankton communities) [47] and (3) the existence of undesirable phytoplankton species to be grazed by the existing zooplankters (which exhibit the maximum abundance in the pre-flood period) and thus the decrease in zooplankton abundance. According to Abdel Aziz and Gharib [48], the relationship between phytoplankton and zooplankton 
usually appears inverse and clear during different periods. The previous studies confirmed that a flood regime substantially affected phytoplankton growth, including high spatial variation along the main canal of Lake Nasser [49]. Similarly, cyanobacteria dominated the phytoplankton in the pre-flood period; however, in the post-flood period, they were also the dominant species, except for site 13 . The phytoplankton assemblages were also strongly dependent on the changes in physical and chemical parameters, including primarily phosphorus and nitrogen. Such relations were also observed in the previous studies [41].

In the current study, zooplankton was represented by 22 taxa belonging to three groups, which ranked as follows: Copepoda $>$ Cladocera $>$ Rotifera. This is in agreement with the previous studies [7,50-52] but with different relative abundance values. The total zooplankton was more abundant in the post-flood period; it might have been due to the flood which facilitated the hatching of the resting eggs lying dormant in littoral zones. Furthermore, the flood increases the quantities of nutrients, hence, the phytoplankton biomass (in terms of the Chl- $a$ content) and zooplankton densities increase and the flood itself enters the lake with a high density of plankton [7]. On the other hand, the decrease in zooplankton in the pre-flood (hot) period could be due to zooplankton movement far away from the hot surface water in line with the temperature increase.

Concerning the history of macrophytes, an invasive species Myriophyllum spicatum has been recorded in Lake Nasser upstream of the Aswan High Dam [53]. However, the changes in the lake environment along with the increase in human activity associated with flood events of the lake led to a high mass invasion of this species [54]. Ali [55] recorded a dense cover of this "nuisance species" (M. spicatum) in Abu Hor. This is in agreement with our current results, where a high biomass of $M$. spicatum was observed at the majority of the sites surveyed. Invasion of this species in the lake has increased throughout the last few years from $66.67 \%$ of the total macrophytes collected in 2013-2014 [56], 77.77\% in $2015,83.78 \%$ in $2016,86.66 \%$ in 2017 and $87.5 \%$ in 2019 to $87.5 \%$ of the total sampling sites in 2020 [57]. Shading by M. spicatum as well as allelopathic substances released by this species may be the cause of invasive capacity and reduced growth of other submerged macrophytes species [58].

In lake ecosystems, epiphytic communities constitute one of the basic elements in the food networks, and the productivity of epiphytic organisms may be equal to or even exceed the phytoplankton and macrophyte productivity ([59] and the references therein). Interactions between benthic algae, phytoplankton and macrophytes can determine the nature of the entire ecosystem as well as the ecosystem responses to the changes in environmental conditions [60]. Epiphytic algae can help by reducing water movement and can be a source of nutrients via the decomposition processes to enhance macrophyte growth [61]. On the contrary, epiphytic algae may also reduce the macrophyte growth. The main mechanisms in epiphyte-macrophyte interactions include the shading and reducing the nutrient diffusion from water to macrophytes and releasing allelopathic compounds by macrophytes to reduce the number of epiphytes [62]. However, the abundance of aquatic flora (including epiphytic algae and macrophytes) is influenced by many abiotic and biotic factors such as temperature, light, $\mathrm{pH}$, nutrients, water level, seasonality, macrophyte morphology ([59] and the references therein). Concerning the Egyptian water bodies, the information on epiphytic algal communities is very scarce [58,63-65]. The results for epiphytic algae, similarly to phytoplankton, showed an increased abundance in the pre-flood period compared to the post-flood period. This finding is not in agreement with the results of Hussian and Haroon [58] who mentioned that the highest total number of epiphytic algae was recorded in the cold season, while the lowest count was recorded in the hot season.

The conditions including the comprehensive insight in the water environment confirmed that the khors of Lake Nasser provide the most important habitat for fish in case of breeding and feeding. Therefore, the fish production in the lake consists mainly of the species caught in khors (tilapias-about $67 \%$ ), followed by those caught in the main channel (silversides Alestes spp-about 18\%, tigerfish Hydrocynus spp-about 6\%, and Nile perch Lates niloticus-about 8\%) [66]. Tilapias consist of three species: Nile tilapias (Oreochromis 
niloticus), mango tilapias (Sarotherodon galilaeus) and redbelly tilapias (Tilapia zillii). The fish production per boat ranged from 24.0 to $31.0 \mathrm{~kg}$ with an average of $27.0 \mathrm{~kg}$ per day [67].

The fish production at Lake Nasser reached its maximum in 1998, with more than 50,000 tons, then it started to decline steadily to less than 19,000 tons in 2016 [66]. About $50 \%$ of the lake fish production is consumed in Upper Egypt (Aswan and the neighboring governorates), and the other $50 \%$ reach the El Obour market to be consumed in Cairo and the vicinity [68]. More than 14,000 fishermen practice fishing on more than 3000 boats in the lake using trammel nets, gill nets and long lines [66,68]. Since 1964, the total of 57 fish species have been recorded in Lake Nasser [69]. Nowadays, a relatively low variety of species was noted from the catches using trammel nets in the lake khors. Nevertheless, the main number of commercial species were from the khors of Lake Nasser, where most of the fishing activities take place in the area from 5.4 to $7.9 \mathrm{~km}$ of the shoreline, depending on the lake water $[70,71]$. Nowadays, the lake fisheries and the ecosystem have undergone negative changes, and biodiversity has declined, obscuring its potential for sustainable development [70,72].

\section{Conclusions}

Current studies were provided to monitor and assess water quality based on the abiotic and biotic parameters including the physicochemical parameters, distribution and structure of bacteria, phytoplankton, zooplankton, macrophytes, epiphytes and fish at the selected sites in Lake Nasser during both the post-flood and pre-flood periods. These periods were the last ones before the storing of the water behind the GERD, which already started (in July 2020). High variations in spatial and temporal distribution were generally found within the parameters studied. The majority of the physicochemical parameters were significantly different between the post-flood and pre-flood periods. The concentrations of $\mathrm{DO}, \mathrm{BOD}, \mathrm{NH}_{4}$ and $\mathrm{SiO}_{4}$ were the exceptions. Higher numbers of cyanobacteria-dominated phytoplankton and total coliforms were recorded in the pre-flood period, especially at sites 10-15. In contrast, zooplankton was more abundant in the post-flood period. The study also indicated the effect of environmental factors on macrophyte distribution as well as the adaptation of $M$. spicatum to thrive under different environmental factors. Macrophytes provided the habitat to other aquatic organisms, including epiphytes, and helped in maintaining the water quality, nutrient cycling and stabilizing the rivers' and lakes' banks. These conditions seem to be favorable for biological processes in general, and especially for fish production.

Supplementary Materials: The following are available online at https:/ / www.mdpi.com/article/10 $.3390 / w 13162195 / \mathrm{s} 1$, Table S1. Zooplankton density (org. $\mathrm{m}^{-3}$ ) in the post- and pre-flood periods at sites $1-15$

Author Contributions: Field study and sampling, M.E.G., A.E.M.H., W.A., S.M.E.-S., U.M.T., M.A.F., M.H.H.; sample processing, M.E.G. and S.M.E.-S. (hydrochemistry), A.E.M.H. and S.A.S. (epiphytes), E.I.A.-A. (phytoplankton), A.M.H. (macrophytes), M.G.N. (zooplankton), U.M.T. (bacteria), W.A. and M.A.F. (fisheries); formal data analysis, A.N.-K.; writing—original draft preparation, all authors; final text, A.N.-K.; writing-review and editing, all authors; approval of the final text, all authors. All authors have read and agreed to the published version of the manuscript.

Funding: This study was undertaken through a comprehensive program of the National Institute of Oceanography and Fisheries to study the environmental conditions of Lake Nasser.

Institutional Review Board Statement: Not applicable.

Informed Consent Statement: Not applicable.

Data Availability Statement: Data is contained only within the article and supplementary material.

Acknowledgments: The research was conducted in the budgetary frame of the National Institute of Oceanography and Fisheries (NIOF) in Cairo and Matrouh University, Marsa Matrouh, Egypt. It was also supported by S. Sakowicz Inland Fisheries Institute in Olsztyn (IFI statutory research topic No. S-009). The authors would like to thank three anonymous reviewers for their helpful comments. 
Conflicts of Interest: The authors declare no conflict of interest.

\section{References}

1. Abou El Ella, S.M.; El Samman, T.A. Ecosystem status of the north part of Lake Nubia African. J. Biol. Sci. 2010, 6, 7-21.

2. Street-Perrott, F.A.; Roberts, N. Fluctuations in closed-basin lakes as an indicator of past atmospheric circulation patterns. In Variations in the Global Water Budget; Street-Perrott, A., Beran, M., Ratcliffe, R., Eds.; Springer: Dordrecht, The Netherlands, 1983; pp. 331-345.

3. Goher, M.E.S.; Farhat, H.; Abdo, M.H.; Salem, S.G. Metal pollution assessment in the surface sediment of Lake Nasser, Egypt. Egypt. J. Aquat. Res. 2014, 40, 213-224. [CrossRef]

4. El-Sheekh, M.M. Impact of Water Quality on Ecosystems of the Nile River. In The Handbook of Environmental Chemistry; Springer Science and Business Media LLC: Cham, Switzerland, 2016; Volume 56, pp. 357-385.

5. Salem, T.A.; Mageed, A.A.A. Assessment of the Impact of the Nile Flood on Food Chain in Lake Nasser-Egypt, with Special Reference to Turbidity. Open J. Ecol. 2021, 11, 41-51. [CrossRef]

6. Goher, M.E.S.; Ali, M.; El-Sayed, S.M. Heavy metals contents in Nasser Lake and the Nile River, Egypt: An overview. Egypt. J. Aquat. Res. 2019, 45, 301-312. [CrossRef]

7. Parmar, T.K.; Rawtani, D.; Agrawal, Y.K. Bioindicators: The natural indicator of environmental pollution. Front. Life Sci. 2016, 9 , 110-118. [CrossRef]

8. Hegab, M.H.; Khalifa, N.; Aly, W. Zooplankton communities in Lake Nasser, Egypt, under the current flood regime, before the construction of Grand Ethiopian Renaissance Dam (GERD). Afr. J. Aquat. Sci. 2020, 2020, 1800443. [CrossRef]

9. Mao, Z.; Gu, X.; Cao, Y.; Zhang, M.; Zeng, Q.; Chen, H.; Shen, R.; Jeppesen, E. The Role of Top-Down and Bottom-Up Control for Phytoplankton in a Subtropical Shallow Eutrophic Lake: Evidence Based on Long-Term Monitoring and Modeling. Ecosystems 2020, 23, 1449-1463. [CrossRef]

10. Castellani, C. Plankton: A Guide to their Ecology and Monitoring for Water Quality. J. Plankton Res. 2009, 32, 261-262. [CrossRef]

11. Napiórkowska-Krzebietke, A. Phytoplankton response to fish-induced environmental changes in a temperate shallow pond-type lake. Arch. Pol. Fish. 2017, 25, 211-262. [CrossRef]

12. Carpenter, S.R.; Lodge, D.M. Effects of submersed macrophytes on ecosystem processes. Aquat. Bot. 1986, 26, 341-370. [CrossRef]

13. Pace, M.; Carpenter, S.R.; Johnson, R.; Kurtzweil, J.T. Zooplankton provide early warnings of a regime shift in a whole lake manipulation. Limnol. Oceanogr. 2013, 58, 525-532. [CrossRef]

14. Wilkinson, G.M.; Carpenter, S.R.; Cole, J.J.; Pace, M.L.; Batt, R.D.; Buelo, C.D.; Kurtzweil, J.T. Early warning signals precede cyanobacterial blooms in multiple whole-lake experiments. Ecol. Monogr. 2018, 88, 188-203. [CrossRef]

15. Wilk-Woźniak, E.; Krzton, W.; Górnik, M. Synergistic impact of socio-economic and climatic changes on the ecosystem of a deep dam reservoir: Case study of the Dobczyce dam reservoir based on a 30-year monitoring study. Sci. Total Environ. 2021, 756, 144055. [CrossRef] [PubMed]

16. Hassan, R.M.; Abdelrahman, E.M.; Tealeb, A.; Zahran, K.H.; Jentzsch, G. Hydrogeological signals due to the seasonal variation of Lake Nasser and its effect on the surrounding crust as deduced from tidal gravity observations. Bull. Inf. Marées Terr. 2010, 146, 11807-11818.

17. American Public Health Association. Standard Methods for the Examination of Water and Waste Water, 22nd ed.; Water Environment Federation: Alexandra, VA, USA, 2012.

18. Utermöhl, H. Zur Vervollkommnung der quantitativen Phytoplankton-Methodik. Mitt. Int. Verein. Limnol. 1958, 9, 1-38. [CrossRef]

19. Guiry, M.D.; Guiry, G.M. AlgaeBase, World-Wide Electronic Publication, National University of Ireland, Galway. 2021. Available online: http:/ / www.algaebase.org (accessed on 8 May 2021).

20. Shannon, C.E.; Weaver, W. The Mathematical Theory of Communication; The University of Illinois Press: Urbana, IL, USA, 1964.

21. Margalef, R. Perspectives in Ecological Theory; University Chicago Press: Chicago, IL, USA, 1968; Volume 111, pp. $313-315$.

22. Pielou, E.C. The measurement of diversity in different types of biological collections. J. Theor. Biol. 1966, 13, 131-144. [CrossRef]

23. Edmondson, W.T. Fresh Water Biology; Wiley: New York, NY, USA, 1959; p. 1248.

24. Pennak, R.W. Fresh-Water Invertebrates of the United States; Wiley: New York, NY, USA, 1978; p. 803.

25. Verheye, H.M.; Dumont, H.J. The calanoid copepods of the Nile system. Hydrobiology 1984, 110, 191-212. [CrossRef]

26. Boulos, L. Flora of Egypt; Checklist All-Hadara Publishing: Cairo, Egypt, 2009; p. 410.

27. Cattaneo, A.; Kerimian, T.; Roberge, M.; Marty, J. Periphyton distribution and abundance on substrata of different size along a gradient of stream trophy de Montréal. Hydrobiology 1997, 354, 101-110. [CrossRef]

28. Ter Braak, C.J.F.; Smilauer, P. Canoco Reference Manual and User's Guide: Software for Ordination (Version 5.10); Microcomputer Power: Ithaca, NY, USA, 2018.

29. Carr, G.M.; Rickwood, C.J. Water Quality Index for Biodiversity Technical Development Document; Report Prepared for Bio-Diversity Indicators Partnership; World Conservation Monitoring Center: Cambridge, UK, 2008; p. 64.

30. El-Halag, R.S.F.; Shaker, I.M.; Mehanna, S.F.; Othman, M.F.; El-Deen Farouk, A. Impact of Some Environmental Condition on Water Quality and Some Heavy metals in Water from Bardawil Lake. N. Y. Sci. J. 2013, 6, 5-13.

31. Hooda, P.; Edwards, A.; Anderson, H.; Miller, A. A review of water quality concerns in livestock farming areas. Sci. Total. Environ. 2000, 250, 143-167. [CrossRef] 
32. Yesuf, H.M.; Assen, M.; Melesse, A.; Alamirew, T. Detecting land use/land cover changes in the Lake Hayq (Ethiopia) drainage basin, 1957-2007. Lakes Reserv. Res. Manag. 2015, 20, 1-18. [CrossRef]

33. Yuan, D.; Zhao, Y.; Guo, X.; Zhai, L.; Wang, X.; Wang, J.; Cui, Y.; He, L.; Yan, C.; Kou, Y. Impact of hydrophyte decomposition on the changes and characteristics of dissolved organic matter in lake water. Ecol. Indic. 2020, 116, 106482. [CrossRef]

34. Imam, N.; El-Sayed, S.M.; Goher, M.E.-S. Risk assessments and spatial distributions of natural radioactivity and heavy metals in Nasser Lake, Egypt. Environ. Sci. Pollut. Res. 2020, 27, 25475-25493. [CrossRef]

35. Technical Memorandum. pH Requirements of Freshwater Aquatic Life; Robertson-Bryan, Inc.: Rancho Cordova, CA, USA, 2004; pp. 1-13.

36. EWQS. Egyptian Drinking Water Quality Standards; Population Decision Number 458; Ministry of Health: Cairo, Egypt, 2007.

37. USEPA. United States Environmental Protection Agency Drinking Water Standards and Health Advisory Tables. 2018. Available online: https: / / www.epa.gov/sites/production/files/2018-03/documents/dwtable2018.pdf. (accessed on 24 April 2017).

38. WHO. World Health Organization, Guidelines for Drinking Water Quality. The Fourth Edition Incorporating the First Addendum 2017. Available online: https://www.who.int/water_sanitation_health/water-quality/guidelines/en/ (accessed on 24 April 2017).

39. Ayers, R.; Westcot, D. Water Quality for Agriculture. In FAO Irrigation and Drainage Paper 29 (Last Updated 1994); Food and Agriculture Organization of the United Nations: Quebec City, QC, Canada, 1985.

40. CCME. Canadian Council of Ministers of the Environment For the protection of aquatic life 2007. In Canadian Environmental Quality Guidelines, 1999; Canadian Council of Ministers of the Environment: Winnipeg, MB, Canada, 1999.

41. Napiorkowska-Krzebietke, A.; Hussian, A.-E.M.; Toufeek, M.A.; El-Monem, A.M.A.; Morsi, H.H. Phytoplankton response to changes of physicochemical variables in Lake Nasser, Egypt. J. Elem. 2012, 20, 855-871. [CrossRef]

42. Abdel, S.S.; Ab, E.I. Impact of Flood Cycle on Phytoplankton and Macroinvertebrates Associated with Myriophyllum spicatum in Lake Nasser Khors (Egypt). J. Biol. Sci. 2018, 18, 51-67. [CrossRef]

43. El-Nashar, W.Y.; Elyamany, A.H. Managing risks of the Grand Ethiopian Renaissance Dam on Egypt. Ain Shams Eng. J. 2018, 9 , 2383-2388. [CrossRef]

44. Aziz, S.A.; Zeleňáková, M.; Mésároš, P.; Purcz, P.; Abd-Elhamid, H. Assessing the Potential Impacts of the Grand Ethiopian Renaissance Dam on Water Resources and Soil Salinity in the Nile Delta, Egypt. Sustainability 2019, 11, 7050. [CrossRef]

45. Joshi, P. Microbial Diversity of Aquatic Ecosystem and its Industrial Potential. J. Bacteriol. Mycol. Open Access 2016, 3, 1-4. [CrossRef]

46. Rochelle-Newall, E.; Nguyen, T.M.H.; Le, T.P.Q.; Sengtaheuanghoung, O.; Ribolzi, O. A short review of fecal indicator bacteria in tropical aquatic ecosystems: Knowledge gaps and future directions. Front. Microbiol. 2015, 6, 308. [CrossRef] [PubMed]

47. Trombetta, T.; Vidussi, F.; Mas, S.; Parin, D.; Simier, M.; Mostajir, B. Water temperature drives phytoplankton blooms in coastal waters. PLoS ONE 2019, 14, e0214933. [CrossRef] [PubMed]

48. Abdel Aziz, N.E.; Gharib, S.M. The interaction between phytoplankton and zooplankton in a Lake-Sea connection, Alexandria, Egypt. Int. J. Ocean. Oceanogr. 2006, 1, 151-165.

49. Zaher, S.S.; Aly, W. Impact of flood regime on phytoplankton communities in the large African reservoir, Lake Nasser, Egypt. Afr. J. Aquat. Sci. 2021, 2021, 1888688. [CrossRef]

50. El-Shabrawy, G.M.; Dumont, H.J. Spatial and seasonal variation of the zooplankton in the coastal zone and main khors of Lake Nasser (Egypt). Hydrobiology 2003, 491, 119-132. [CrossRef]

51. El-Serafy, S.S.; Mageed, A.A.; Hesham, R. Impact of flood on the distribution of zooplankton in Lake Nasser khors-Egypt. J. Egypt. Acad. Environ. Dev. 2009, 10, 121-141.

52. Khalifa, N.; El-Damhogy, K.A.; Fishar, M.R.; Nasef, A.M.; Hegab, M.H. Vertical distribution of zooplankton in Lake Nasser. Egypt. J. Aquat. Res. 2015, 41, 177-185. [CrossRef]

53. Idso, S.B. Relative Rates of Evaporative Water Losses from Open and Vegetation Covered Water Bodies. J. Am. Water Resour. Assoc. 1981, 17, 46-48. [CrossRef]

54. Crundwell, M.E. A review of hydrophyte evapotranspiration. Rev. Hydrobiol. Trop. 1986, 19, $215-232$.

55. Ali, M.M. Aquatic macrophytes in Egyptian Nubia pre and post-formation of Lake Nasser. In Sustainable Fish Production in Lake Nasser: Ecological Basis and Management Policy; Craig, J.F., Ed.; International Centel for LIVing AquatiC Resources Management: Laguna, Philippine, 2000; pp. 61-65.

56. Haroon, A.M. Long Term Changes of Macrophytes in Lake Nasser. In Ecological Basis for Lake Nasser Ecosystem; El shabrawy, G., Ed.; Lambert Academic Publishing: Saarbrücken, Germany, 2014; pp. 169-192.

57. Haroon, A.M.; Abd Ellah, R.G. Variability response of aquatic macrophytes in inland lakes: Case study Lake Nasser, Egypt. Egypt. J. Aquat. Res. 2021, 46, 103-115.

58. Hussian, A.M.; Haroon, A.M. Sensitivity of submerged aquatic macrophytes and their epiphytic microalgae to the different environmental variables in River Nile, Egypt. Int. J. Ecol. Environ. Sci. 2019, 45, 107-122.

59. Adam, M.S.; Hifney, A.F.; Fawzy, M.A.; Al-Badaani, A.A. Seasonal biodiversity and ecological studies on the epiphytic microalgae communities in polluted and unpolluted aquatic ecosystem at Assiut, Egypt. Eur. J. Ecol. 2017, 3, 92-106. [CrossRef]

60. Dos Santos, T.R.; Castilho, M.C.; Henry, R.; Ferragut, C. Relationship between epipelon, epiphyton and phytoplankton in two limnological phases in a shallow tropical reservoir with high Nymphaea coverage. Hydrobiology 2020, 847, 1121-1137. [CrossRef] 
61. Carvalho, C.; Hepp, L.U.; Palma-Silva, C.; Albertoni, E.F. Decomposition of macrophytes in a shallow subtropical lake. Limnological 2015, 53, 1-9. [CrossRef]

62. Körner, S.H. Nee Allelopathic inhibition of epiphytes by submerged macrophytes. Aquat. Bot. 2006, 85, 252-256. [CrossRef]

63. Abd El-Karim, M.S.; Fishar, M.R.; Abdel Gawad, S.S. Epiphytic algae and macroinvertebrates communities of Myriophyllum spicatum Lemm and their cascade in the littoral food web of Lake Nasser, Egypt. Glob. Vet. 2009, 3, 165-177.

64. Fawzy, M.A. Spatial distribution of epiphytic algae growing on the aquatic macrophytes Phragmites australis and Echinochloa stagnina at Assuit-Egypt. Minia Sci. Bull. 2016, 2, 1-26.

65. Abdel-Aal, E.I. Species composition and diversity of epiphytic microalgae on Myriophyllum spicatum in the El-Ibrahimia Canal, Egypt. Afr. J. Aquat. Sci. 2021, 2021, 1884523. [CrossRef]

66. GAFRD. Fisheries Statistics Yearbook; General Authority for Fish Resources Development: Cairo, Egypt, 2018.

67. YEAG. Youth Employment in Aswan Governorate Project; Report of Fisheries Assessment of Lake Nasser, Aswan-Egypt; World Fish Center: Penang, Malaysia, 2017.

68. Nasr-Allah, A.M.; Habib, O.A.; Dickson, M.; Dickson, C. Value Chain Analysis of Lake Nasser Fisheries in Aswan, Upper Egypt; Program Report: 2016-11; World Fish Center: Penang, Malaysia, 2016.

69. Bishai, H.; Abdel Malek, S.; Khalil, M. Lake Nasser. Egyptian Environmental Affairs Agency (EEAA production); National Biodiversity Unit: Cairo, Egypt, 2000; Volume 11, p. 577.

70. Halls, A.S.; Habib, O.A.; Nasr-Allah, A.M.; Dickson, M. Lake Nasser Fisheries: Literature Review and Situation Analysis; Program Report: 2015-42; World Fish Center: Penang, Malaysia, 2015.

71. Zwieten, P.A.M.; Bene, C.; Kolding, J.; Brummett, R.; Valbo-Jorgensen, J. Review of Tropical Reservoirs and Their Fisheries-The Cases of Lake Nasser, Lake Volta and Indo-Gangetic Basin Reservoirs; FAO Fisheries and Aquaculture Technical Paper, No. 557; Food and Agriculture Organization of the United Nation: Rome, Italy, 2011.

72. El-Far, A.; Aly, W.; El-Haweet, A.E.-D.; Nasr-Allah, A.; Karisa, H. Fisheries management based on gear selectivity of a tropical reservoir, Lake Nasser, Egypt. Egypt. J. Aquat. Res. 2020, 46, 71-77. [CrossRef] 